\title{
The Use of Well-Log Data in the Geomechanical Characterization of Middle Cambrian Tight Sandstone Formation: A Case Study from Eastern Pomerania, Poland
}

\author{
Małgorzata Słota-Valim * and Anita Lis-Śledziona (D) \\ Oil and Gas Institute—NRI, Lubicz Street 25A, 31-503 Krakow, Poland; lis@inig.pl \\ * Correspondence: slota@inig.pl; Tel.: +48-126177683
}

Citation: Słota-Valim, M.;

Lis-Śledziona, A. The Use of Well-Log

Data in the Geomechanical

Characterization of Middle Cambrian Tight Sandstone Formation: A Case

Study from Eastern Pomerania,

Poland. Energies 2021, 14, 6022.

https://doi.org/10.3390/en14196022

Academic Editor: Jadwiga A. Jarzyna

Received: 6 August 2021

Accepted: 17 September 2021

Published: 22 September 2021

Publisher's Note: MDPI stays neutral with regard to jurisdictional claims in published maps and institutional affiliations.

Copyright: (c) 2021 by the authors. Licensee MDPI, Basel, Switzerland. This article is an open access article distributed under the terms and conditions of the Creative Commons Attribution (CC BY) license (https:/ / creativecommons.org/licenses/by/ $4.0 /)$.

\begin{abstract}
Geomechanical characterization plays a key role in optimizing the stimulation treatment of tight reservoir formations. Petrophysical models help classify the reservoir rock as the conventional or unconventional type and determine hydrocarbon-saturated zones. Geomechanical and petrophysical models are fundamentally based on well-log data that provide reliable and high-resolution information, and are used to determine various relationships between measured borehole parameters and modeled physical rock properties in 3D space, with the support of seismic data. This paper presents the geomechanical characterization of the Middle Cambrian $(\mathrm{Cm} 2)$ sediments from Eastern Pomerania, north Poland. To achieve the aim of this study, 1D well-log-based and 3D models based on seismic data of the rocks' petrophysical, elastic, and strength properties, as well as numerical methods, were used. The analysis of the Middle Cambrian deposits revealed vertical and horizontal heterogeneity in brittleness, the direction of horizontal stresses, and the fracturing pressure required to initiate hydraulic fractures. The most prone to fracturing is the gas-saturated tight sandstones belonging to the Paradoxides Paradoxissimus formation of $\mathrm{Cm} 2$, exhibiting the highest brittleness and highest fracturing pressure necessary to stimulate this unconventional reservoir formation.
\end{abstract}

Keywords: tight sandstone reservoir; reservoir characterization; well-log data; geomechanical modeling; fracturing pressure; stress field

\section{Introduction}

In contrast to conventional sandstone reservoirs exhibiting good transport properties, including porosity and permeability, tight reservoir rocks are characterized by the presence of smaller and disconnected pore space, resulting in very low permeability. When holding hydrocarbons accumulations, these tight reservoirs need to be stimulated via hydraulic fracturing to achieve production at economical rates. As the effectiveness of the stimulation treatment is strongly dependent on the mechanical state in the reservoir, a comprehensive geomechanical study should be performed to determine the stress field in order to optimize well placement and trajectory, as well as to determine the magnitude of pressure at which hydraulic fractures will open with optimal geometry at the desired location [1-3].

In this study, we aimed to characterize tight Middle Cambrian sandstones from Eastern Pomerania, north Poland. The overlying shale formation of Lower Paleozoic in the study area was the subject of intensive exploration a few years ago regarding the potential occurrence of hydrocarbons in the unconventional shale formation [4-10]. The Middle Cambrian sandstones lying beneath were not explored to this extent, but some studies were dedicated to the characterization of tectonics, lithostratigraphy, or hydrocarbons potential [11-21]. The evaluated reservoir rock developed as fine- to medium-grained quartzitic sandstones rarely interbedded with thin layers of claystones or mudstones, but the dominant layers are sandstones with an admixture of pyrite [12]. These sandstones, with a maximum thickness reaching up to $80 \mathrm{~m}$, are considered the main potential hydrocarbons reservoir in the lower Paleozoic strata. Natural gases occurring in Middle Cambrian 
sandstones in the onshore Polish Baltic region are related with oil accumulated in the reservoir rock of Middle Cambrian age and are originated from a source containing type II kerogen [19]. The overlaying shales formed in the Upper Cambrian and Tremadocian ages constitute a sealing layer for the Middle Cambrian sandstones and are considered the source rocks of highest hydrocarbon potential in the Lower Paleozoic interval [21].

This paper provides the results of an investigation conducted in the Middle Cambrian sandstones aiming to optimize the stimulation treatment of the tight sandstone reservoir [13]. The reservoir was characterized using a wide variety of modern data, including borehole data supported by 3D seismic data. The interpretation of this input data combination resulted in the development of geomechanical models and the use of numerical methods to determine the stress field and areas suitable for stimulation treatment to ultimately optimize the well placement, trajectory, and technical parameters of stimulation treatment of the Middle Cambrian tight sandstones in the study area.

\section{Geological Setting}

The study was conducted in Peribaltic Syneclise, in the onshore part of north Poland. The geological setting of the research area is dictated by the Teyseiere-Tornquist Zone (T-T Zone) separating the Precambrian platform (part of the East European Craton, EEC) from the Paleozoic epiCaledonian platform [22] (Figure 1). The deposits located in the northeastern part of Poland can be considered a result of the development of the Baltic Basin, which commenced in the late Vendian in the current area of northeast Poland, Kaliningrad region, the Peribaltic countries, and the southerly part of the present Baltic Sea. The main phase of basin development occurred in the Early Paleozoic in the westerly part of the EEC craton, this being a basement $[12,14,17,22]$.

In the study area, no significant tectonic deformations affecting the structure of analyzed sediments were documented. The deposits of Lower Palaeozoic are lying nearly horizontally on the crystalline basement. Within the Early Palaeozoic and Precambrian strata, two major fault complexes were identified based on the 3D seismic data in the study area. The first fault system is composed of faults propagating through the uppermost part of the Precambrian, Cambrian, and Ordovician sediments. The second, subordinate fault complex, consists of faults occurring only in the top part of the Precambrian sediments, terminates in Cambrian and appears only as a flexure in Ordovician strata. The faults identified in Early Palaeozoic sediments generally are characterized by NE-SW and SE-NW direction, wherein the second fault system appears to be subordinate and complementary to the first. Most of the interpreted faults are reversed [23]. The identified fault system is likely the result of reactivation of the old fault system in the basement with NE-SW and WSW-ENE arrangement in response to prevailing stresses in Caledonian Orogeny, caused by Avalonia and Baltica collision [22].

The Middle Cambrian deposits evaluated in this study comprise the first and second of four Lower Paleozoic depositional sequences distinguished in the northern part of Poland and the Polish part of the Baltic Sea.

The bottom-most Middle Cambrian deposits are assigned to the first depositional sequence, belonging to the Sarbsko formation with a total thickness exceeding $200 \mathrm{~m}$. The deposits of the Sarbsko formation developed as black claystones, dark grey mudstones, and mudstone-sandstone with heterolytic structures in deposits assigned to the Acadoparadoxides Oelandicus and lower part of the Paradoxides Paradoxissimus zones [12]. The Sarbsko formation is overlain by the Debki formation, assigned to Paradoxides Paradoxissimus and is represented by light-grey, fine- to medium- grained quartz sandstones, rarely interbedded with sandstone-mudstone deposits. The Debki formation being the main focus of this study, with a thickness reaching up to $80 \mathrm{~m}$, is considered the hydrocarbons reservoir with the most potential in the Lower Paleozoic strata [11,12,20,21,24]. 


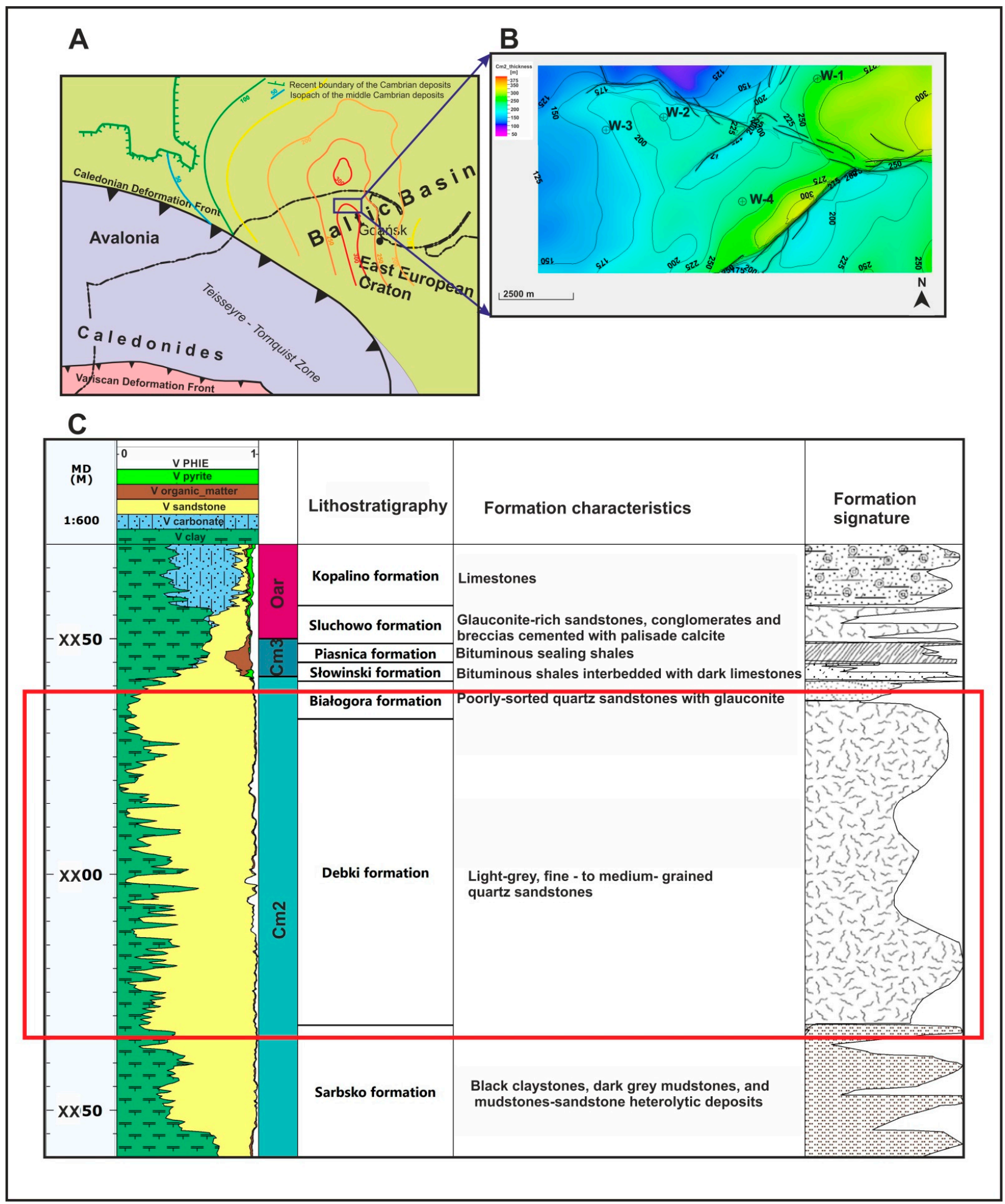

Figure 1. Location of the study area on a background paleothickness map of Middle Cambrian deposits (changed after 12; [25]) (A), detailed thickness map constructed for the investigated Middle Cambrian deposits with the arrangement of occurring fault system marked with black lines and the location of analyzed boreholes W-1-4 (B), and the exemplary lithostratigraphic profile including Arenig (Oar), Upper Cambrian (Cm3) and Middle Cambrian sediments (Cm2) in borehole W-3 with the lithostratigraphical units description after 12 (C). 
The overlaying mudstones and mudstone-sandstone heterolytic deposits, reaching up to $30 \mathrm{~m}$, assigned to the Osiek formation, belong to the uppermost part of the Middle Cambrian Paradoxides Paradoxissimus Zone.

The second depositional sequence beginning with the Bialogora formation consists of poorly sorted quartz sandstones with glauconite and frequently present phosphoritic clasts. These locally occurring sediments with a maximum thickness of $4 \mathrm{~m}$ belong to the Paradoxides Forchhammeri zone. The upper-most Middle Cambrian sediments are represented by the Slowinski formation, developed as organic rich shales interbedded with thin dark limestones [12]. The overlaying bituminous shales of the Piasnica formation of the Upper Cambrian and Tremadocian age not only constitute a sealing layer for the Middle Cambrian sandstones but are also the best source rocks in Lower Paleozoic strata [21].

\section{Methodology}

In this study, the petrophysical and geomechanical properties of the Middle Cambrian deposits were evaluated primarily using well-log data. The well-log data were interpreted using Techlog software (Schlumberger, Houston, TX, USA), where 1D models of the geomechanical and petrophysical parameters confirming the tight nature of the sandstone reservoir were developed. The interpretation results obtained were modeled in defined 3D space, driven by 3D seismic data in Petrel software (Schlumberger). The constructed 3D models of petrophysical properties include density and porosity, whereas the geomechanical parameters include elastic properties (including Young modulus and Poisson's ratio) and strength properties (uniaxial compressive strength (UCS), tensile strength (T), and friction angle (FA)). Together with the determined direction and magnitude of tectonic stresses as boundary conditions, these models were used as an input for geomechanical simulations run with the Visage geomechanical simulator (Schlumberger). This simulation provided the stress field, which, together with an estimated spatial distribution of elastic properties, was essential in determining optimal borehole location, the trajectory of the horizontal wells, and the technological parameters of stimulation treatment of the Middle Cambrian tight sandstones.

The schematic workflow of the study is depicted in Figure 2.
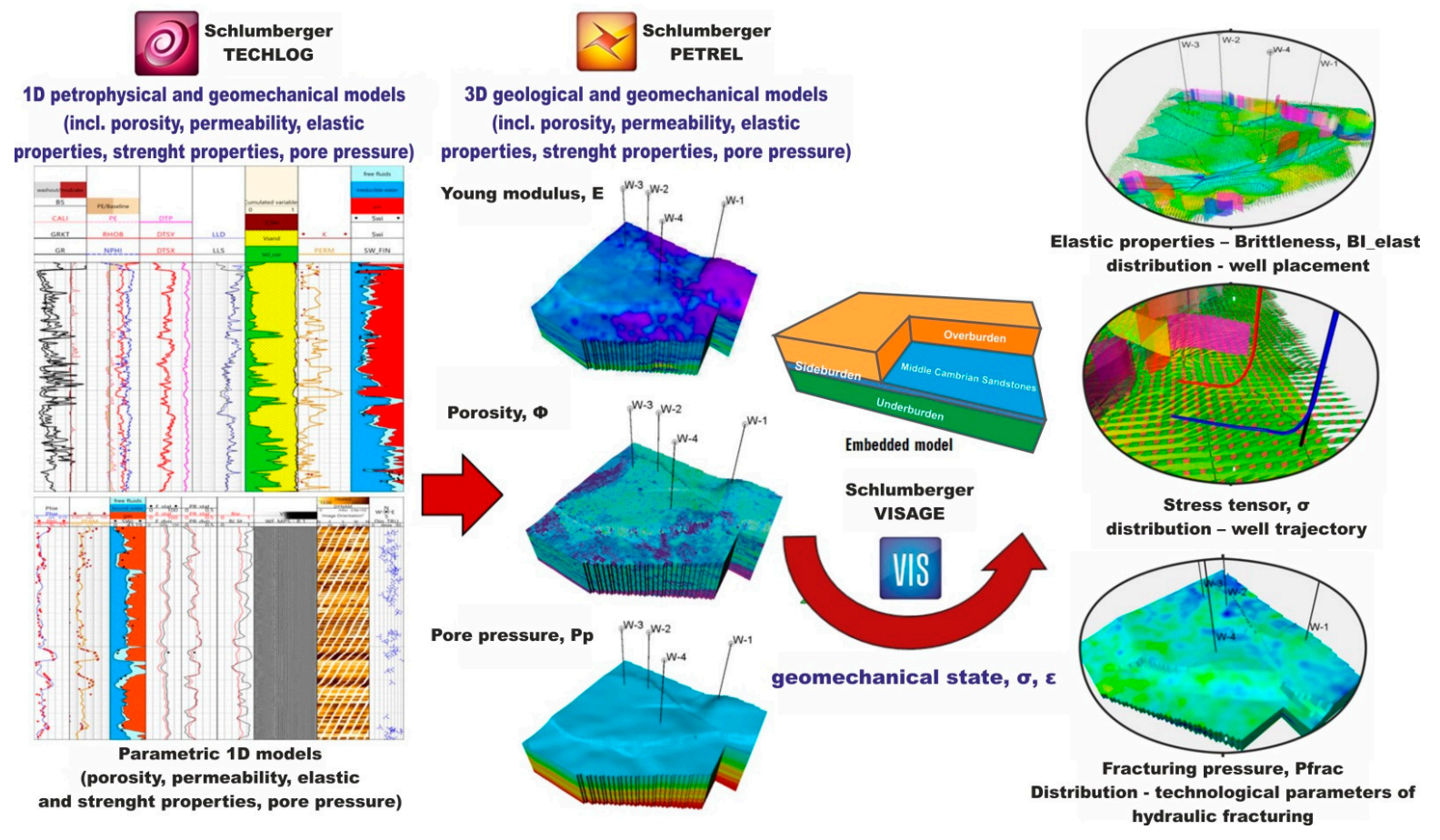

Figure 2. Schematic workflow for characterization of Middle Cambrian tight sandstones. 


\subsection{Relevant Input Data}

The interpretation was conducted in four boreholes: $\mathrm{W}-1, \mathrm{~W}-2, \mathrm{~W}-3$, and $\mathrm{W}-4$, the location of which is shown in Figure 1. The selected wells had a wide range of well logs available to perform the petrophysical interpretation and build the geomechanical model. The well-log datasets in Figure 3 contain: gamma ray (GR), caliper (CALI), uranium concentration (URAN), thorium concertation (THOR), potassium concentration (POTA), bulk density (RHOB), neutron porosity (NPHI), compressional and shear slowness (DTP and DTS, respectively), photoelectric factor (PE), and deep and shallow laterolog resistivity (LLD and LLS, respectively). A wide range of laboratory measurements of core porosity, permeability, water saturation (NMR), and mineral content (X-ray diffraction, XRD) allowed us to calibrate the petrophysical properties calculated from well logs [26]. The shale volume was calculated based on the gamma ray and thorium concentration, and calibrated with the results of XRD available from W-2. XRD is a technique used for the identification and quantitative analyses of rock mineral composition by determining the crystallographic structure of mineral components of the rock. The powdered sample is irradiated with incident $\mathrm{X}$-rays, and intensities and scattering angles of the $\mathrm{X}$-rays that leave the material are measured. The mineral identification is possible as each mineral has different atomic arrangements corresponding to different patterns with different intensities.

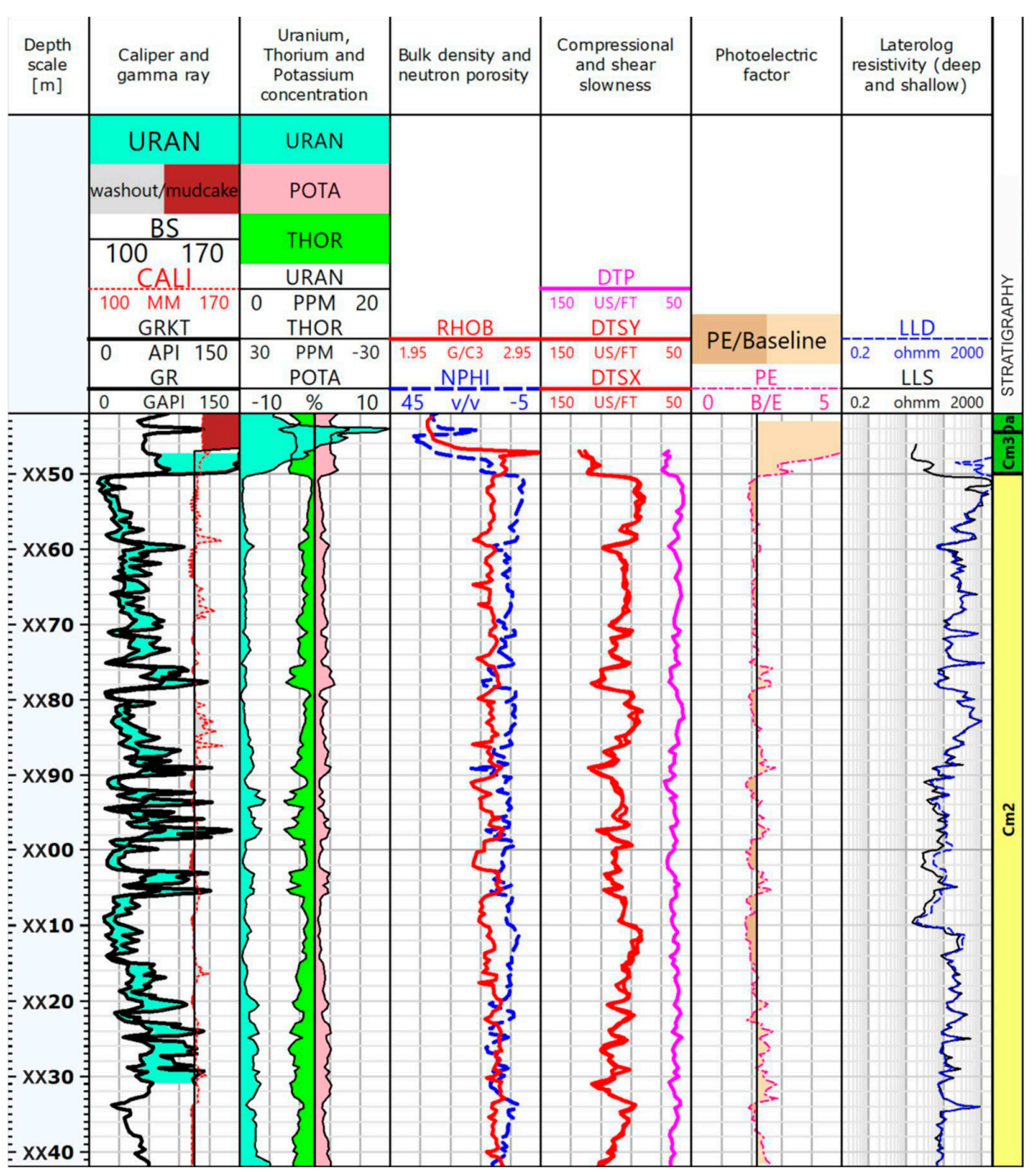

Figure 3. The dataset with available well-log data from well W-2.

Effective porosity was derived from the neutron-density cross-plot method and calibrated with core porosity measured with the use of the mercury porosimetry method [26]. 
In this method by forced injection of mercury into the pore space of the tested material, it is possible to calculate the critical diameter of the capillary into which mercury can penetrate under a given injection pressure, as well as other parameters characterizing the pore space, e.g., effective porosity and bulk density.

TOC content in the Cm2pp interval was obtained from the correlation between uranium concertation and TOC content from laboratory Rock-Eval measurements [26]. The TOC is measured during Rock-Eval Pyrolysis, during which the organic content in the rock sample is decomposed in oxygen absence, followed by combustion. The quantity of hydrocarbons and carbon dioxide released during this process allow for the determination of the richness and maturity of potential source rocks. The water saturation of tight sandstone layers was calculated from well logs with the use of Archie equation.

Full-wave sonic waveforms acquired by the Halliburton Wave Sonic Tool enabled the calculation of the rocks' dynamic elastic properties. Full-wave acoustic logging is a new-generation tool that enables a better understanding of the wave propagation around a borehole. The acoustic wavetrain is composed of compressional, shear, and Stoneley waves. Table 1 presents the results of laboratory rock mechanical tests carried out on a few samples collected from W-1, W-3, and W-4. Poisson's ratio (PRstat) and Young's modulus (Estat) were determined on the core samples using conventional triaxial mechanical tests based on the analyses of sample deformation after applying principal stresses with constant confining pressure $\mathrm{P}(\sigma 1>\sigma 2=\sigma 3=\mathrm{P})$. Borehole microresistivity images from the XRMI tool were also available for the selected wells. As mentioned, for 3D modeling of the petrophysical and geomechanical parameters, in addition to the well-log data, seismic data were used in the form of the amplitude cube covering the area of interest of approximately $117 \mathrm{~km}^{2}$. The 3D seismic data, calibrated with stratigraphical borehole markers, were the primary source of information used to construct the 3D structural model.

Table 1. Rock mechanical parameter testing in wells $W-1, W-3$, and $W-4$.

\begin{tabular}{ccccccccc}
\hline $\begin{array}{c}\text { Sample } \\
\text { ID }\end{array}$ & $\begin{array}{c}\text { Young's } \\
\text { modulus }\end{array}$ & $\begin{array}{c}\text { Poison } \\
\text { ratio }\end{array}$ & $\begin{array}{c}\text { Sample } \\
\text { ID }\end{array}$ & $\begin{array}{c}\text { Young's } \\
\text { modulus }\end{array}$ & $\begin{array}{c}\text { Poison } \\
\text { ratio }\end{array}$ & $\begin{array}{c}\text { Sample } \\
\text { ID }\end{array}$ & $\begin{array}{c}\text { Young's } \\
\text { modulus }\end{array}$ & $\begin{array}{c}\text { Poison } \\
\text { ratio }\end{array}$ \\
\hline & GPA & unitless & & GPA & unitless & & GPA & unitless \\
\hline 1 & 68.5116 & 0.21 & 1 & 63.2 & 0.12 & 1 & 66.78501 & 0.16 \\
\hline 2 & 69.7472 & 0.21 & 2 & 63.7 & 0.18 & 2 & 61.75184 & 0.15 \\
\hline 3 & 67.6272 & 0.21 & 3 & 49.1 & 0.18 & 3 & 62.79811 & 0.18 \\
\hline 4 & 76.0011 & 0.17 & & & & & & \\
\hline
\end{tabular}

\subsection{Determination of Elastic Parameters}

Based on the measured compressional slowness (DTP), shear slowness (DTS), and bulk density (RHOB), the dynamic elastic moduli of reservoir were calculated with the use of equations for isotropic rocks [27]:

$$
\begin{gathered}
E_{d y n}=\rho \times V s^{2} \times\left[\frac{3 \times V p^{2}-4 \times V s^{2}}{V p^{2}-V s^{2}}\right] \\
P R_{d y n}=\frac{V p^{2}-2 \times V s^{2}}{2 \times\left(V p^{2}-V s^{2}\right)}
\end{gathered}
$$

where $\rho$ is the log-derived bulk density, $V p$ stands for the P-wave velocity calculated from the DTP, and $V s$ is the S-wave velocity calculated from the DTS.

Static laboratory values of the elastic moduli were used to calculate and calibrate the continuous curves of the static Young's modulus (E_stat) and Poisson's ratio (PR_stat). Due to the limited core measurements from the Middle Cambrian sandstone formation, the results of the measurements of the Young's modulus and Poisson's ratio carried out 
on Ordovician and Silurian core samples were referenced to help determine a relationship between the static and dynamic moduli. The Silurian and Ordovician shales lie directly above the Middle Cambrian rocks and might be source rocks for the underlying sandstones.

\subsection{Calculation of the Brittleness Index (BI)}

The brittleness index $\left(\mathrm{BI}_{\text {lit }}\right)$ was calculated based on the lithology Javrie's equation [28] and with the use of dynamic Young's modulus and Poisson's ratio values (BIe):

$$
\text { BI_lit }=\frac{\text { Vsand }}{\text { Vsand }+ \text { Vcl }+ \text { Vker }}
$$

where Vsand is the quartz volume in the fraction, $\mathrm{Vcl}$ is the clay volume in the fraction, and Vker is the kerogen volume in the fraction.

$$
\mathrm{BIe}=\mathrm{E} \_\mathrm{dyn}+\frac{\text { PR_dyn }}{2}
$$

where E_dyn is the dynamic values of the Young's modulus calculated from well logs and PR_dyn is the dynamic values of Poisson's ratio calculated from well logs.

The mechanical properties of tight sandstones play an important role in the identification of the intervals for hydraulic fracturing, which enables the exploration of hydrocarbons from the zones of low porosity and permeability [13]. The brittleness is a function of mineral composition, anisotropy, pressure, temperature, diagenesis and compaction processes, and the elastic properties of the rock. An increase in quartz or carbonates increases the brittleness of the rock, whereas an increase in clay minerals increases the plasticity. However, the intervals with high plasticity stabilize the borehole and prevent the wellbore from collapsing. Brittleness is one of the parameters that can be used to guide the selection of fracturing targets in unconventional reservoirs such as shales or tight reservoirs.

\subsection{Determination of the Stress Field}

In unconventional reservoir characterization, the knowledge of the distribution of principal stresses plays a critical role in stimulation treatment design, as the stress distribution controls the geometry of the generated hydraulic fractures. To reconstruct the spatial distributions of tectonic stresses, the boundary conditions were first determined and then applied in the geomechanical simulation.

The stress field within the 3D structural model was calculated using the finite element method implemented in the geomechanical simulator Visage (Schlumberger). A series of parametric models describing the mechanical behavior of the rock medium with determined boundary conditions was necessary to deploy the geomechanical simulator and calculate the stress field. To estimate the orientation of the minimum and maximum horizontal stresses in the borehole profiles, we analyzed the XRMI images, which capture the borehole damage zones and identify the direction of the principal horizontal stresses. The magnitude of the stresses was established with the use of the results of a hydraulic fracturing test performed in one of the boreholes within the study area. The estimated tectonic stresses were then used as boundary conditions in the geomechanical simulation to calculate stress field within the Middle Cambrian sandstones.

The analyses conducted on wellbore microresistivity images captured the drillinginduced damage zones in the borehole wall, e.g., breakouts occurring in the orientation parallel to the minimum horizontal stress and drilling-induced fractures (DIFFS), which in turn indicate the regional direction of maximum horizontal stress [29-32]. Breakouts and drilling-induced fractures indicate that the borehole stresses exceed the rock strength in compression or tension, respectively [33-36]. The XRMI images were interpreted for four wells. The main concern was to identify the borehole breakouts and drilling-induced fractures, providing valuable information about the horizontal stress directions. The breakouts are recognized as high-conductivity or low-conductivity (in oil-base mud) enlargements of the borehole walls [37]. They can also be interpreted based on the bulk density curve 
as they lower the bulk density values and cause caliper enlargements on the opposite site of the borehole. In turn, tensile fractures usually develop parallel to the maximum horizontal stress [38], and they can be identified on XRMI images as conductive pairs of narrow features.

The magnitude of the minimum horizontal stress $(\sigma \mathrm{h})$ was estimated based on hydraulic fracturing treatment, in which the analyses of the pressure drop trend from the moment the stimulation fluid is pumped out allowed for the determination of the closure pressure $(\mathrm{Pc})$. The magnitude of $\mathrm{Pc}$ is equal to the pressure of the fluid in the fracture, balancing the minimum horizontal stress value acting in the opposite direction to the fracture opening. Therefore, Pc provides an estimate of the value of the minimum horizontal stress oh [39].

Another fundamental element of the geomechanical model is pore pressure. The pore pressure is the pressure imposed by the fluid filling the pore space at a given depth, counteracting the magnitude of the principal stresses $[40,41]$. The pore pressure in the borehole profiles was estimated in particular intervals with the Bowers method based on acoustics (slowness), as shown in Figure 3. The physical concept of the Bowers method is well-known and described in many papers [42-44].

The calculated pore pressure curves were calibrated against pore pressure point data estimated with the D-exponent method. This method uses the relationship between the current formation pressure and drilling parameters such as rate of penetration, weight on bit, and rotation per minute [45].

The stress field was calculated during geomechanical simulation, which used the previously developed 3D models of the petrophysical and geomechanical parameters and the determined boundary conditions. The simulation was run under an isotropic medium assumption using Coulomb Mohr failure criteria and von Mises failure criteria for rock salt intervals occurring in the overburden. Finally, the results of the geomechanical simulation were used to indicate the preferable horizontal well trajectory and calculate the injection pressure in hydraulic fracturing treatment.

\section{Characterization of Petrophysical and Elastic Properties}

In this paper we show the results of the investigation conducted in the Middle Cambrian sandstones from Eastern Pomerania, North Poland. The petrophysical properties were evaluated to determine the hydrocarbon potential and confirm the unconventional character of the reservoir, requiring the stimulation treatment. The spatial distributions of geomechanical properties of the analyzed reservoir rock, on the other hand, were necessary to determine the areas prone to hydraulic fracturing and calculate the stress field, allowing the horizontal well trajectory and stimulation treatment parameters to be optimized.

\subsection{The Results of Petrophysical Interpretation}

The reservoir rock developed as layers of clean sandstones interbedded with thin layers of claystones or mudstones, but the dominant layer is sandstone with an admixture of pyrite. The most prospective are sandstones with thin interlayers of sand-silt heteroliths. The porosity of sandstones is diverse and does not exceed $10 \%$. The porosity and the interconnection of pore space were mainly reduced as a result of the quartz cementation process. The other factors impacting the reservoir porosity include compaction, cementation, and dissolution [17]. The interpretation of XRMI borehole images shows the presence of natural and drilling-induced fractures. The cracks are filled with bitumen, quartz, or carbonates. The fractures constitute additional potential paths for hydrocarbon migration, and their presence contributes to the reservoir's dual porosity system. The sandstones are hydrocarbon-saturated. The calculated average water saturation coefficient is low, approx. $40 \%$. The perforation in the reservoir interval indicates the presence of gas and gasoline. The shale volume in sandstone intervals is low, below 10\%. The overburden organic-rich Upper Cambrian shales that formed as claystones and mudstones with carbonates are potential source rocks for hydrocarbon accumulation in the sandstones of the 
Middle Cambrian age. The total organic carbon content in shales is as high as $10 \%$. Total organic carbon was determined with the use of the Bowman method [46] and calibrated with the Rock-Eval measurements of TOC content. The results of XRMI interpretation indicate the presence of high-resistivity carbonates among the low-resistivity claystones. The Rock-Eval analysis performed on cores derived from Middle Cambrian rocks in well $\mathrm{W}-2$ also indicates the presence of organic matter in mudstone and claystone intervals. The TOC content does not exceed $1.3 \%$.

The observed low permeability of these distinguished reservoir facies allowed us to classify them as tight sandstones. For tight reservoirs, stimulation treatment such as hydraulic fracturing is required to obtain economic volumes of gas at an economical gas flow rate. The heterogeneity of the sandstone reservoir can be observed in the porosity and permeability changes (Figure 4A). Two trends of dependence between porosity and permeability can be observed: one is related to intergranular porosity and shows a proportional increase in permeability with increasing porosity; the other shows an increase in permeability even if the porosity is low, indicating the presence of natural fractures in the reservoir. The pore sizes of the evaluated reservoir do not exceed $2 \mu \mathrm{m}$, and are positively correlated with permeability. The pore sizes of $1.5 \mu \mathrm{m}$ have approximately $3 \mathrm{mD}$ of absolute permeability (Figure 4B).
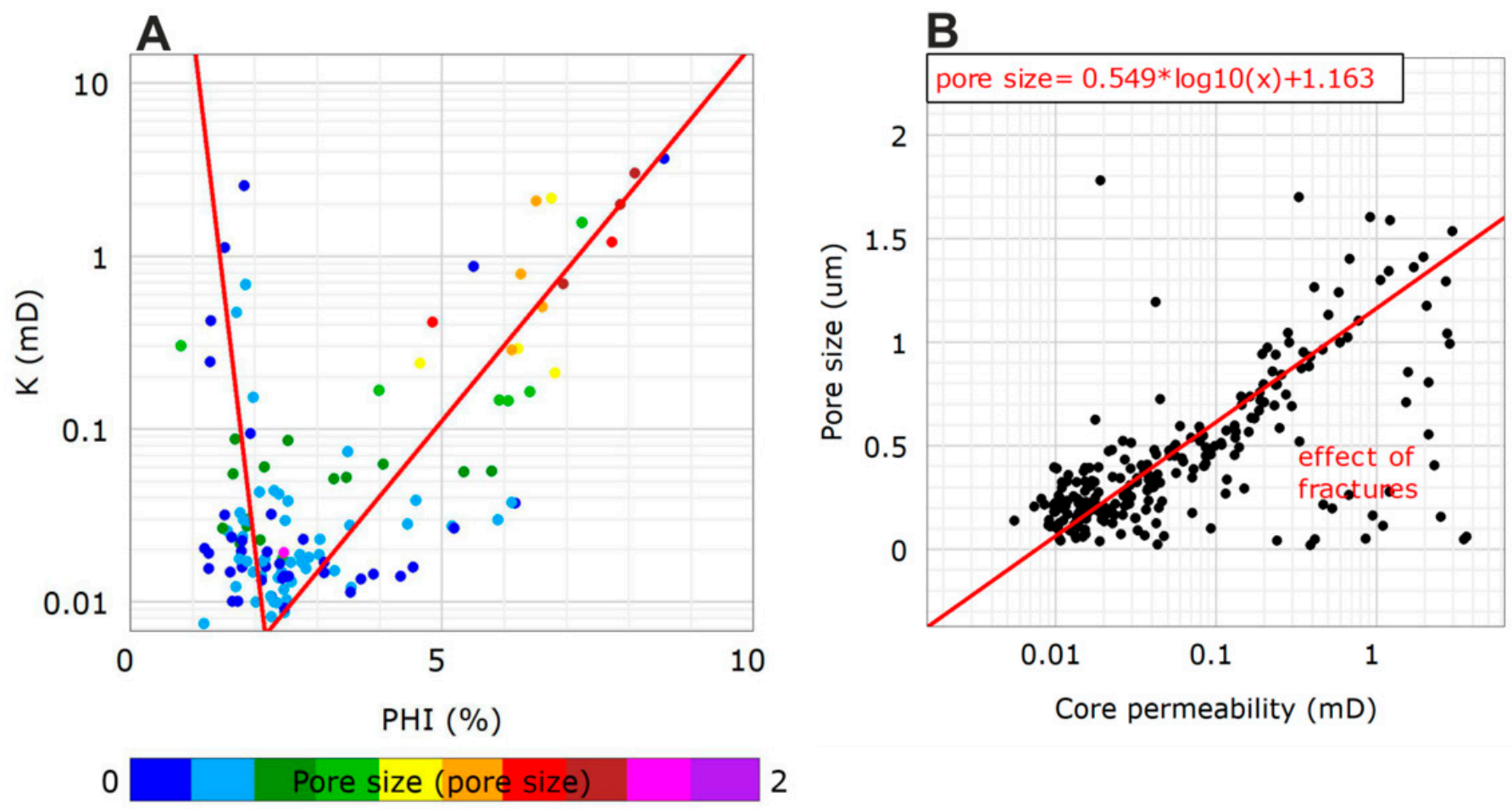

Figure 4. Cross-plot of laboratory-measured (A) porosity and permeability in well W-3, with the color scale referring to dynamic Young's modulus values, and (B) average pore sizes and permeability.

\subsection{Characterization of Elastic Parameters and Brittleness Index}

The calculated values of the dynamic elastic properties provide important information about the intervals subjected to hydraulic fracturing treatment. These intervals were identified using high Young's modulus values, which identify intervals with higher stiffness and low Poisson's ratio. In Figure 5, we present the cross-plots between the static Young's modulus and Poisson's ratio, both measured on core samples and the dynamic Young's modulus and Poisson's ratio calculated with the use of wireline acoustic and density logging data. The relationships between static and dynamic moduli are described by the equations presented in Figure 5. 
The results in Figure 5 show higher values of Young modulus for Cambrian sandstones than in Lower Paleozoic shale formation, while the values of Poison's Ratio for Cambrian sandstones have similar values for shales. The values of Poisson's Ratio are affected by the gas present in the pore space.
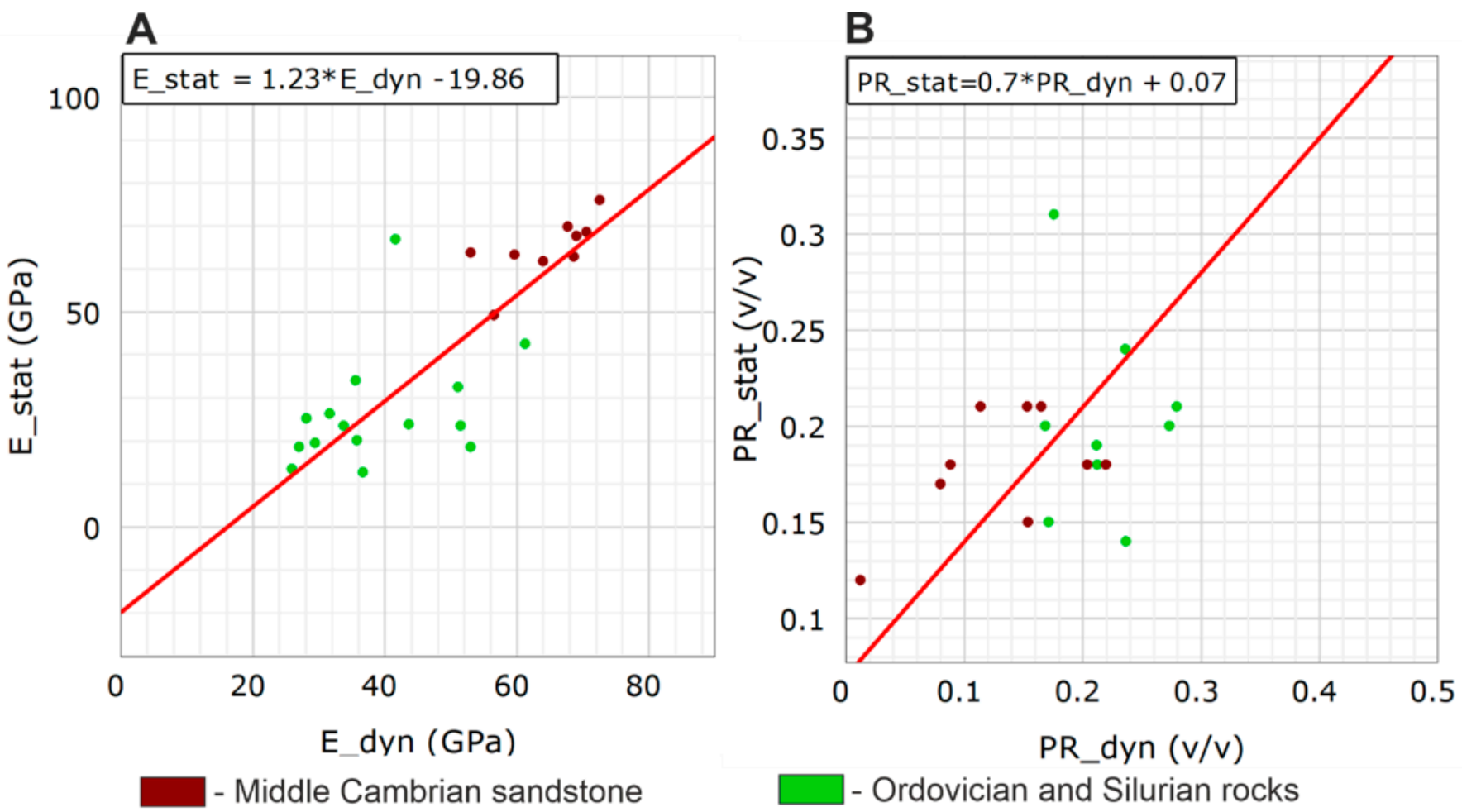

Figure 5. Cross-plot between static laboratory-measured (A) Young's modulus values and dynamic Young's modulus calculated from well logs, and (B) Poisson's ratios and dynamic Poisson's ratios calculated from well logs.

The intervals with low permeability in the profile of the Middle Cambrian reservoir rock are displayed in Figure 6A. The Young's modulus has a positive linear correlation with the volume of quartz (Figure 6B,C). Young's modulus values decrease in the intervals with higher porosity and permeability. Track eight in Figure 6A, marked in orange, indicates the intervals with a Young's modulus values higher than $60 \mathrm{GPa}$ and a Poisson's ratio below 0.2, identifying the zones with the highest stiffness. The calculated BI_lit and BIe in well W-3 are compiled in the cross-plot in Figure 6D,E. The color scale indicates the dynamic Young's modulus values. A BI_lit above 0.8 and BIe above 0.6 correspond to intervals to be subjected to hydraulic fracturing. These zone are also characterized by high Young's modulus values above $60 \mathrm{GPa}$. The BIe values in sandstone intervals are around 0.2 lower than BI_lit, probably caused by the brittleness based on lithology not considering the influence of in situ stress and pressures. The brittleness calculated using the dynamic elastic properties of the rock includes these factors. BIe is also more sensitive to porosity changes, showing higher values in the intervals with higher stiffness and low porosity (BIe approx. 0.7) and lower values in the intervals with higher porosity (BIe approx. 0.5). Due to the heterogeneity of geomechanicalproperties in the Cambrian sandstone formation, the interval was subdivided into three units of different rock mechanic properties. For the hierarchical rock analysis (HRA) clustering method, we used Young's modulus, Poisson's ratio, and brittleness data as the inputs. HRA is a method developed by TerraTek and is available in Techlog software (Schlumberger). This method provides a color-coded classification of an analyzed interval of rocks as a function of depth. The method uses advanced statistical tools, including principal component analysis (PCA) and cluster analysis, to find the unique HRA classification based on a set of measurements. As 
a result, the average values of input data, clay volume, effective porosity, permeability, and brittleness (BI_lit) were calculated for each group (Table 2).

Table 2. The average values of dynamic elastic properties (E_dyn, PR_dyn), brittleness (BIe), shale volume ( $\mathrm{Vcl})$, volume of quartz (Vsand), effective porosity (Phie), absolute permeability (Perm), brittleness based on lithology (BI_lit) in three geomechanically different units.

\begin{tabular}{|c|c|c|c|c|c|c|c|c|c|}
\hline $\begin{array}{l}\text { Well } \\
\text { Name }\end{array}$ & Units Name & $\begin{array}{l}\text { Average } \\
\text { E_dyn }\end{array}$ & $\begin{array}{l}\text { Average } \\
\text { PR_dyn }\end{array}$ & $\begin{array}{l}\text { Average } \\
\text { BIe }\end{array}$ & $\begin{array}{l}\text { Average } \\
\text { Vcl }\end{array}$ & $\begin{array}{l}\text { Average } \\
\text { Vsand }\end{array}$ & $\begin{array}{l}\text { Average } \\
\text { Phie }\end{array}$ & $\begin{array}{l}\text { Average } \\
\text { Perm }\end{array}$ & $\begin{array}{l}\text { Average } \\
\text { BI_lit }\end{array}$ \\
\hline & & GPa & unitless & unitless & $v / v$ & $v / v$ & $v / v$ & $\mathrm{mD}$ & $v / v$ \\
\hline \multirow{3}{*}{ W-1 } & \multirow{3}{*}{$\begin{array}{l}\text { 1. Tight sandstone } \\
\text { 2. Sandstone of } \\
\text { higher porosity } \\
\text { 3. Mudstone }\end{array}$} & 68.669 & 0.133 & 0.687 & 0.155 & 0.813 & 0.032 & 0.015 & 0.832 \\
\hline & & 61.183 & 0.218 & 0.613 & 0.285 & 0.680 & 0.034 & 0.015 & 0.690 \\
\hline & & 37.686 & 0.277 & 0.378 & 0.596 & 0.381 & 0.022 & 0.006 & 0.334 \\
\hline \multirow{3}{*}{$\mathrm{W}-2$} & \multirow{3}{*}{$\begin{array}{l}\text { 1. Tight sandstone } \\
\text { 2. Sandstone of } \\
\text { higher porosity } \\
\text { 3. Mudstone }\end{array}$} & 68.615 & 0.115 & 0.687 & 0.159 & 0.812 & 0.029 & 0.068 & 0.833 \\
\hline & & 58.553 & 0.191 & 0.586 & 0.319 & 0.646 & 0.035 & 0.11 & 0.666 \\
\hline & & 46.618 & 0.270 & 0.468 & 0.511 & 0.463 & 0.026 & 0.054 & 0.467 \\
\hline \multirow{3}{*}{ W-3 } & \multirow{3}{*}{$\begin{array}{l}\text { 1. Tight sandstone } \\
\text { 2. Sandstone of } \\
\text { higher porosity } \\
\text { 3. Mudstone }\end{array}$} & 67.934 & 0.091 & 0.680 & 0.129 & 0.846 & 0.024 & 0.018 & 0.862 \\
\hline & & 60.187 & 0.169 & 0.603 & 0.253 & 0.720 & 0.028 & 0.022 & 0.732 \\
\hline & & 50.039 & 0.243 & 0.502 & 0.407 & 0.571 & 0.022 & 0.012 & 0.569 \\
\hline \multirow{3}{*}{ W-4 } & \multirow{3}{*}{$\begin{array}{l}\text { 1. Tight sandstone } \\
\text { 2. Sandstone of } \\
\text { higher porosity } \\
\text { 3. Mudstone }\end{array}$} & 71.620 & 0.166 & 0.717 & 0.213 & 0.757 & 0.031 & 0.011 & 0.778 \\
\hline & & 62.821 & 0.190 & 0.629 & 0.290 & 0.668 & 0.042 & 0.026 & 0.695 \\
\hline & & 50.754 & 0.268 & 0.509 & 0.482 & 0.491 & 0.027 & 0.008 & 0.498 \\
\hline
\end{tabular}

Permeability was calculated as the geometric mean, while the other parameters as the arithmetic mean. Track 8 in Figure 6A shows the subdivided units in well W-3 in color. We observed that unit one has the best properties for fracturing. It has the highest Young's modulus, ranging from $68-71 \mathrm{GPa}$, brittleness BIe of 0.69 , and BI_lit of 0.8, and Poisson's ratio values approximately 0.1 The lowest values of Poisson ratio corresponds to gas saturated low-porosity intervals with the highest volume of quartz [47]. Wide range of performed qualitative analysis indicates that rock with low Poisson's ratio represents formation with high values of Young's modulus and better brittleness [48]. The clay volume is the lowest in unit one and reaches the highest values in unit three, which is characterized by higher plasticity. The Young's modulus in unit two, on average, is $60 \mathrm{GPa}$ and the Poisson's ratio is 0.2 . This unit represents sandstones with the highest porosity, $4 \%$ on average, and average permeability of about $0.11 \mathrm{mD}$. Poisson's ratio reaches the highest values in mudstones and claystones, and decreases as the volume of quartz increases.

The results of the petrophysical interpretation of the Middle Cambrian sandstone reservoir (Figures 6A and 7) exhibit the variability in the petrophysical parameters such as clay volume, effective porosity, permeability, and fluids saturation [18,49]. The well-log interpretation results were calibrated with XRD laboratory measurements of core samples to obtain accurate clay and sandstone volume values and are presented on tracks two and three in Figure 7. The calculated values of TOC content were also calibrated with the results of the Rock-Eval laboratory measurements. Kerogen volume within mudstone intervals do not exceed 3\%. The intervals with relatively high porosity and permeability are interbedded with tight sandstone and mudstone intervals. Irreducible water saturation ranges from $15 \%$ in porous sandstones to $55-65 \%$ in mudstones, and up to $80 \%$ in claystone intervals. The gas saturation reaches up to $60-70 \%$. Well tests performed in well W-2 show non-water production from the reservoir zone. The results of perforations were a weak flow of natural gas and $50 \mathrm{~mL}$ of gasoline Figure $6 \mathrm{~A}$ presents the 1D petrophysical model of the analyzed reservoir subdivided into three units of different geomechanical parameters. The dots in tracks 3-7 represent the values of laboratory-measured parameters: porosity, permeability, irreducible water saturation, static Young's modulus, and Poisson's ratio (in track 7). Figure 6B,C show the relationship between the volume of quartz and Young's modulus values for unit 1 of low permeability (Figure 6B) and for unit two represents 
sandstone of higher permeability (Figure 6C). Unit one has the highest stiffness; Young's modulus values exceed 0.6 GPa while Poisson's ratio is lower than 0.2. Figure 6D,E show the dependence between brittleness calculated based on lithology (BI_lit) and dynamic elastic moduli (BIe) for unit one of low permeability (Figure 6D) and unit two of higher permeability (Figure 6E). Both BI_lit and BIe indicate high values for low permeability unit; BI_lit is higher than 0.7, and BIe is higher than 0.6.

A

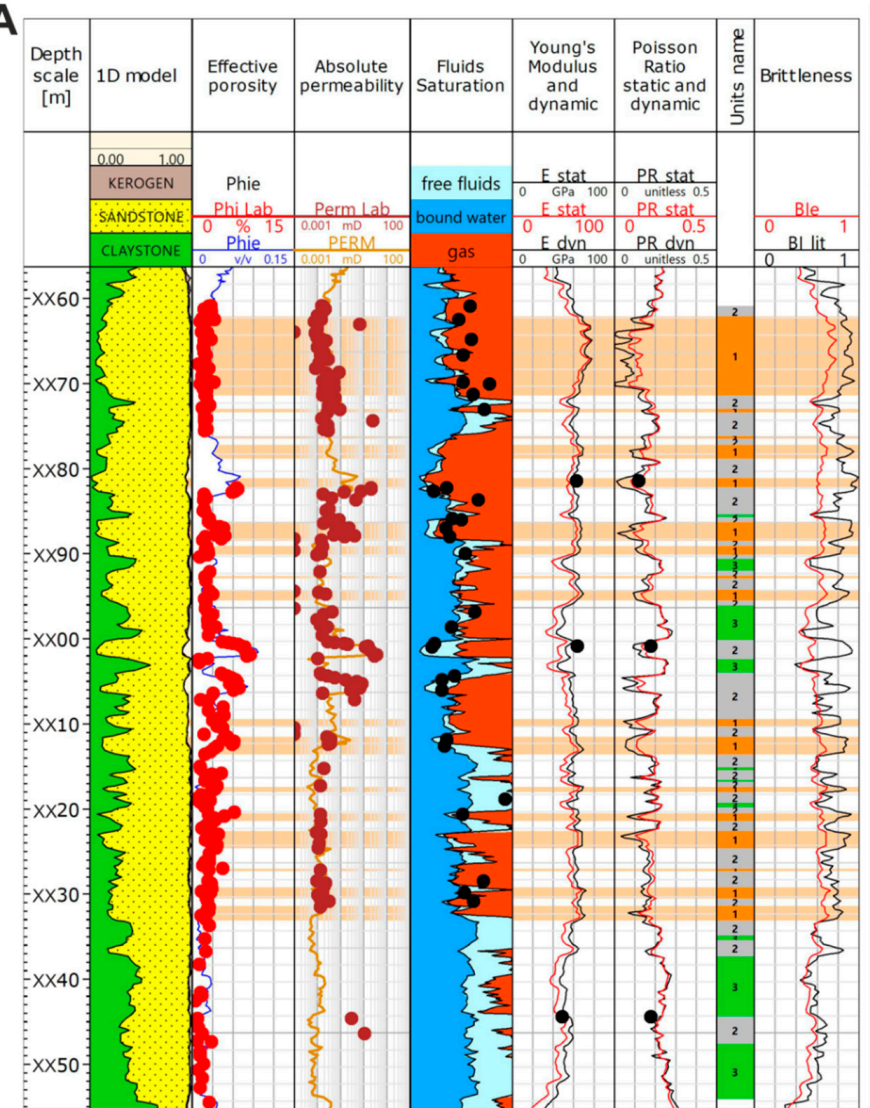

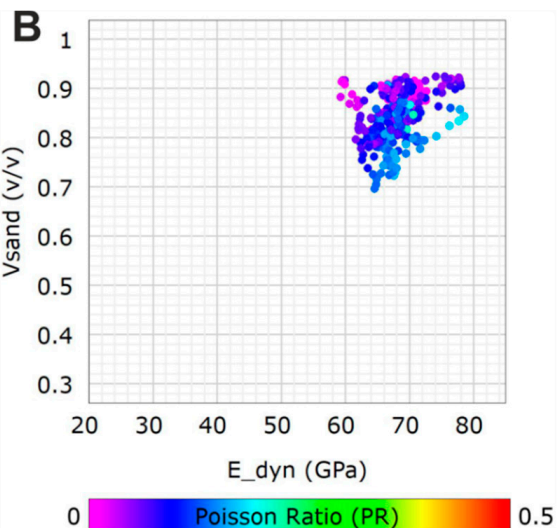

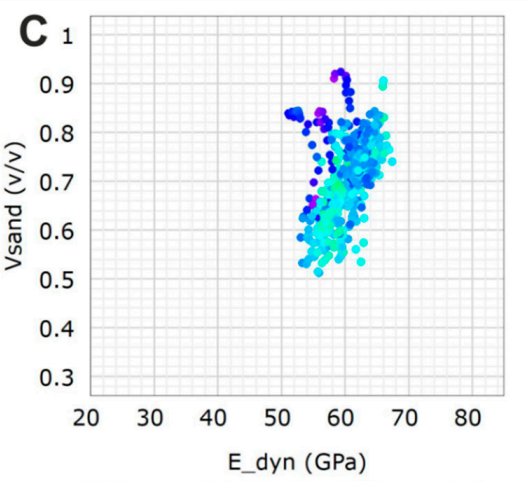

$0 \quad$ Poisson Ratio (PR)

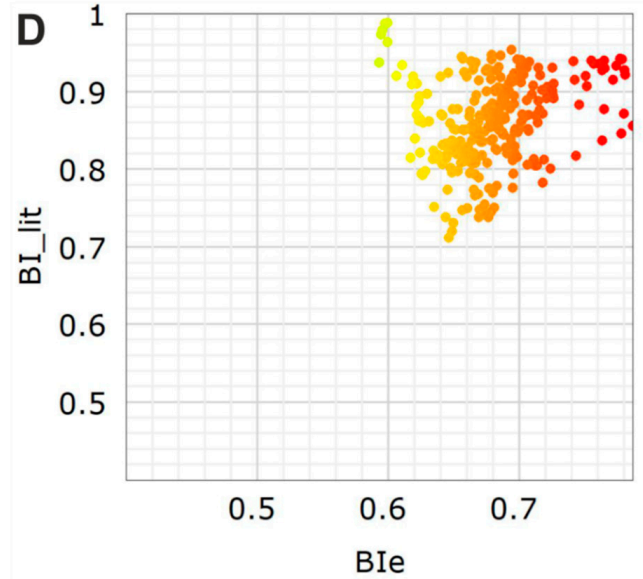

Young_Modulus (E_dyn) 80

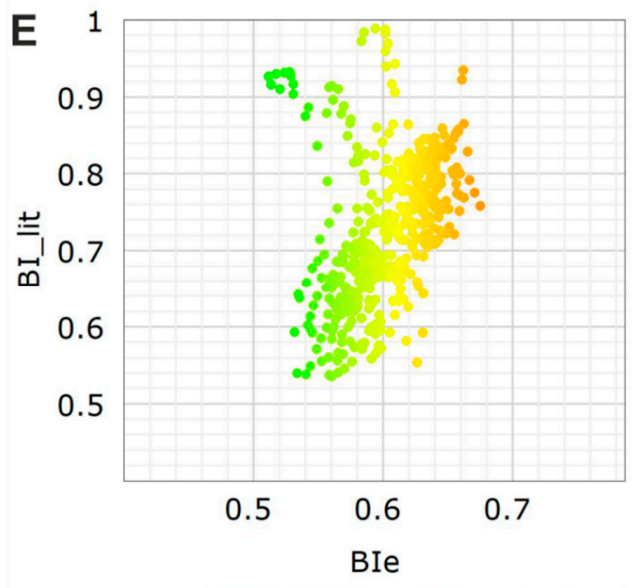

$0 \quad$ Young_Modulus (E_dyn) 80

Figure 6. Geomechanical and petrophysical characterization in borehole W-3: petrophysical and geomechanical interpretation of Middle Cambrian sandstone reservoir in well W-3 (A), cross-plot between the volume of quartz (Vsand) and dynamic Young's modulus (E_dyn) for unit one (tight sandstone) (B), cross-plot between the volume of quartz (Vsand) and dynamic Young's modulus (E_dyn) for unit two (sandstone of higher porosity) (C), cross-plot between brittleness BI_lit and BIe for unit 1, color scale refers to Young's Modulus values (D) cross-plot between brittleness BI_lit and BIe for unit 2, color scale refers to Young's modulus values (E). 


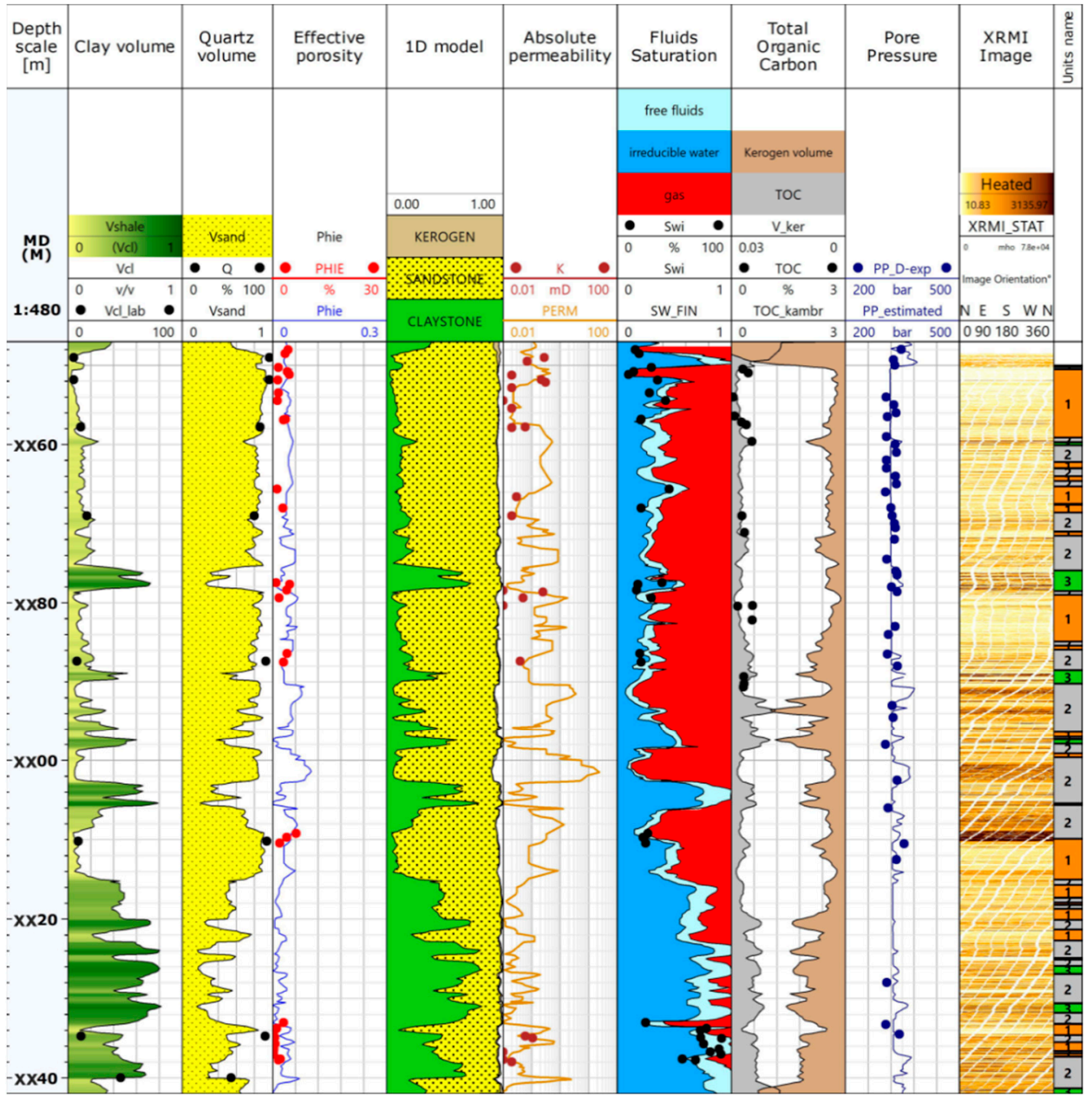

Figure 7. Geomechanical and petrophysical properties of the Middle Cambrian reservoir calculated from well logs and calibrated with laboratory measurements in well W-2.

Figure 7 presents the 1D petrophysical, core-calibrated model evaluated from well $\log$ data. The following petrophysical parameters were calculated: volumes of minerals, porosity, permeability, water saturation, TOC (total organic carbon) content, and pore pressure. In additional detail, a high-resolution XRMI conductive image is presented in track 10. Claystones and porous sandstone show high conductivity, while low permeability sandstone indicates low conductivity due to the presence of tight gas in pore space. Microresistivity imagers measure conductivity of the invaded zone in the sandstone intervals of higher porosity and permeability; in the unflushed zones they are saturated with gas but, as can be seen on the borehole image, in the flushed zone gas was replaced with brine, while tight sandstone intervals are still gas saturated even in invaded zone. These intervals due to low permeability need to be fractured to release the hydrocarbons.

The spatial distribution of brittleness BI_elast was calculated using the relation in Equation (4), characterizing brittleness as a function of elastic properties. Young's modulus and Poisson's ratio were first calculated using the compressional and shear velocity cube, as well as the density cube, resulting from simultaneous inversion applying the relation in Equations (1) and (2), respectively. The average values of BI_elast were calculated for the entire Middle Cambrian sediments (Figure 8A) and for the sandstones with the highest reservoir potential belonging to the Cm2pp (Figure 8B). 


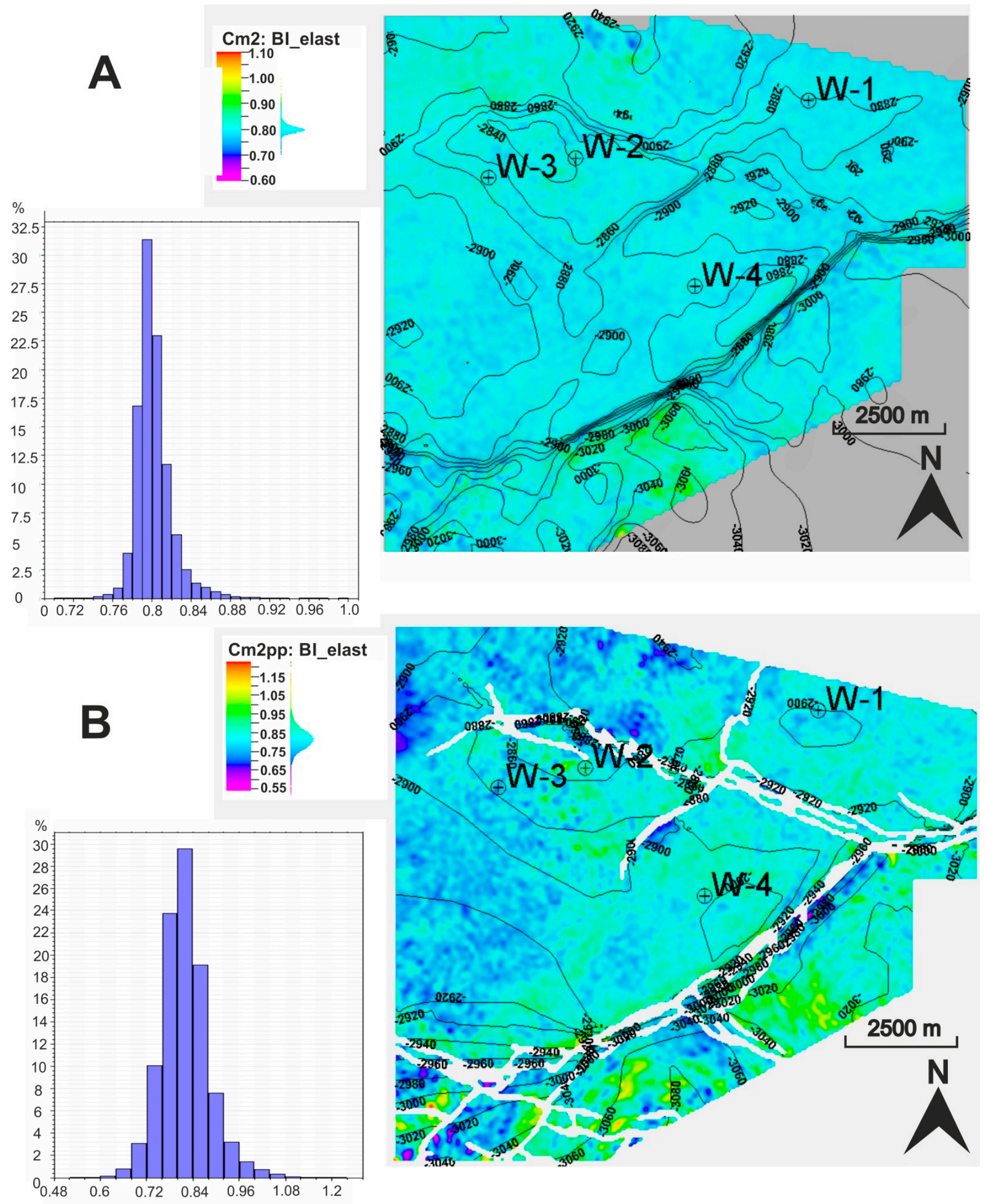

Figure 8. Average BI_elast calculated with the use of results of seismic inversion in the interval (A) of the Middle Cambrian $(\mathrm{Cm} 2)$ and $(\mathbf{B})$ the evaluated reservoir interval of sandstones of the Paradoxides Paradoximus. 
Middle Cambrian sediments are characterized by a BI of approximately 0.8 , with the occurrence of more brittle areas in the central part and those located to the south of the fault zone, an area of deeper buried sediments. In the Paradoxides Paradoxissimus interval of the Middle Cambrian age, the sediments are, on average, more brittle, with a BI_elast of approximately 0.85 . The sandstones reveal a wider range of BI, with the least-brittle sandstones in the northern part and the highest brittleness in the deeper buried area located toward the south of the dislocation zones.

The average brittleness of the Middle Cambrian sandstones is lowered by the contribution of less-brittle sediments located in the top-most and bottom part in the profile of $\mathrm{Cm} 2$, exhibiting an increased content of clay (Figures 6A and 7).

\section{Characterization of the Stress Field}

Based on the interpretation of XRMI images capturing the damage zones in the borehole wall, such as breakouts and drilling-induced fractures (Figure 9A,B), we determined the direction of present horizontal stresses.

\subsection{Estimation of Horizontal Stress Direction (Based on XRMI Images)}

Although the breakouts and tensile fractures are mainly visible in the overlying Lower Paleozoic shale formation, it was also possible to identify these structures in the Middle Cambrian sandstones. They are particularly well-recognized in well W-4. The azimuth direction of breakouts is around 50-70 NE and 190-230 SW (Figure 9C). In the direction perpendicular to the breakouts, some tensile fractures can be observed. They are mainly visible in Caradok in well W-2 and are identified in Cambrian sandstone in well W-4. The azimuth direction of drilling-induced fractures ranges from 110-130 SE and 290-310 NW (Figure 9C). The borehole failure in the study wells was used to define the orientations of the maximum (Shmax) and minimum (Shmin) horizontal stress (Figure 9D). Accurately determining the minimum and maximum horizontal stress directions allow the optimal design of the horizontal wells' trajectories. To increase the effectiveness of the planned reservoir rock stimulation treatment, they should be drilled in the direction of the minimum horizontal stress [38]. Notably, most of the tensile fractures occur in the intervals defined as unit one, which has the highest stiffness, expressed by a higher Young's modulus and brittleness (BI_elast) predefined for fracturing treatment.

To assess the effective stresses, we determined the pore pressure in the borehole profile first. W-2 was used as the reference well due to its available dense calibration data set. The estimated pore pressure in the Middle Cambrian sandstone formation is at approximately 300 bars; however, there are clearly visible zones with elevated pore pressure, reaching up to 400 bars (track 9 in Figure 7). The zones with increased pore pressure are located at the very top of the Middle Cambrian sediments, two zones in the middle of the profile, and two other zones localized closer to the bottom of the analyzed interval.

Determined from the reference $\mathrm{W}-2$ borehole, fitting parameters were used in the remaining three boreholes, which had few or no calibration data. The obtained profiles were then used to interpolate the pore pressure in the 3D structural model.

Statistical analysis of the pore pressure profiles of the four boreholes allowed us to determine the parameters controlling the interpolation process of the input data in the 3D structural geological model. Spatial modeling was preceded by a stage of arithmetic averaging of high-resolution pore pressure profiles with a resolution of $0.1 \mathrm{~m}$, up to 3D model resolution in the upscaling process. The estimated pore pressure was then used in the geomechanical simulation. 

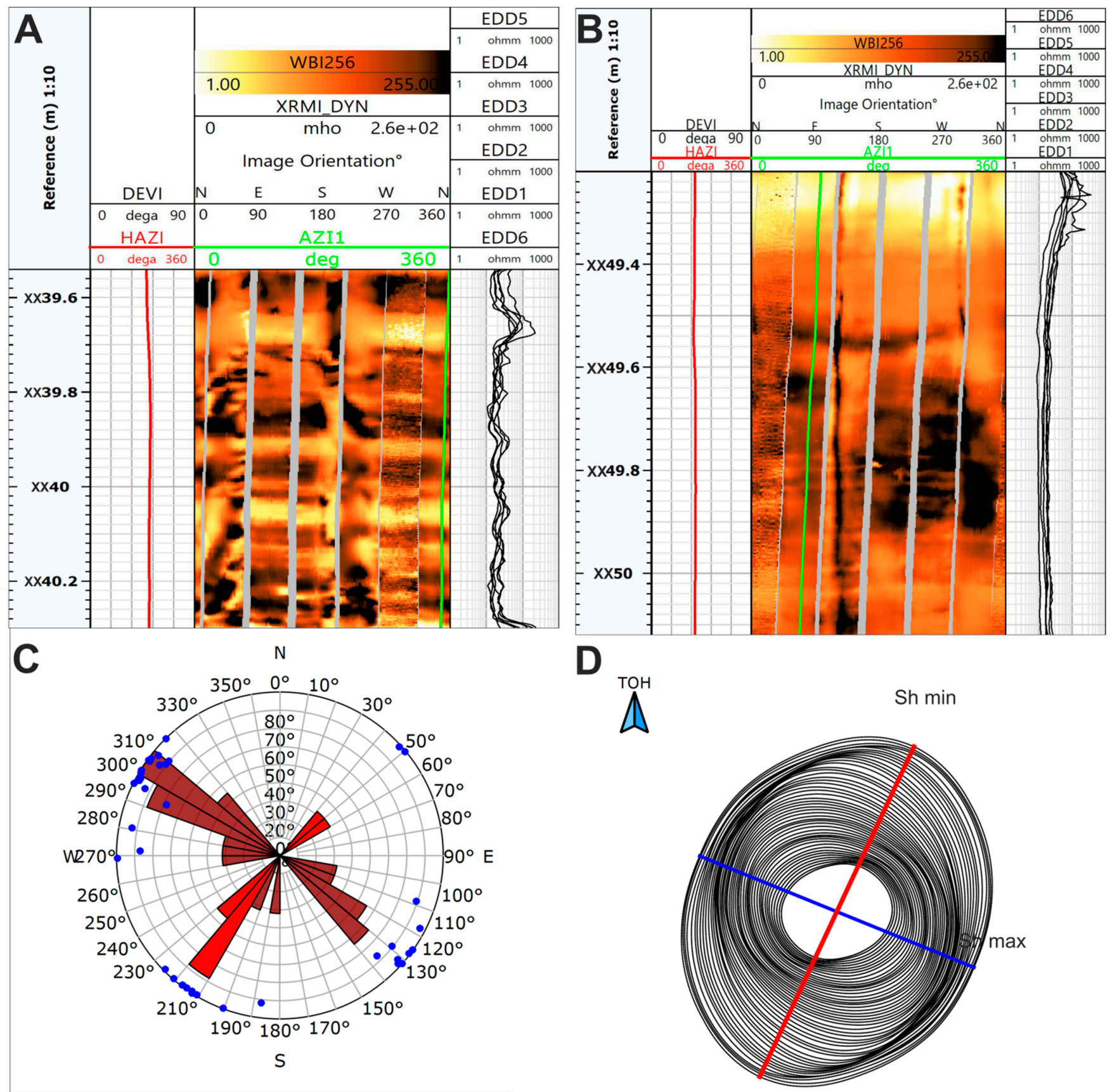

D

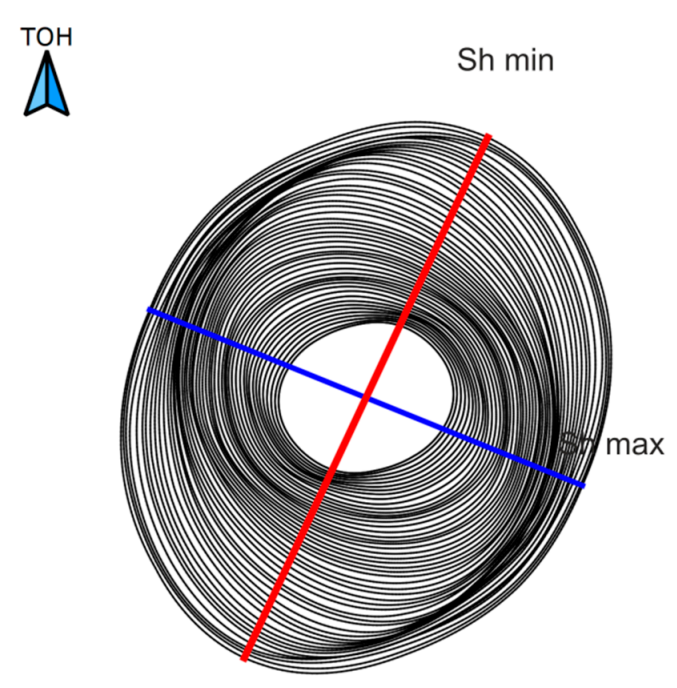

Dip_TRU (dega) / Azimuth (dega)

\section{Simple filter:}

Breakout

STensile fractures

Figure 9. Analysis results of W-4 borehole images (A) breakouts, (B) drilling induced fractures, (C) rose diagram depicting Table 3, (D) determined direction of the minimum and maximum horizontal stress, marked with red and blue line, respectively.

Table 3. Initial principal stresses acting in Middle Cambrian sandstones.

\begin{tabular}{cc}
\hline Gradient $\boldsymbol{\sigma h}$ & $0.0197(\mathrm{MPa} / \mathrm{m})$ \\
\hline $\boldsymbol{\sigma H} / \boldsymbol{\sigma h}$ & 1.16 \\
Azimuth $\boldsymbol{\sigma h}_{\left({ }^{\circ}\right)}$ & 50.00 \\
\hline
\end{tabular}




\subsection{Stress Field and Fracturing Pressure}

The distribution of stresses acting in the Middle Cambrian sandstones was calculated during geomechanical simulation using the geomechanical simulator Visage (Schlumberger). Numerous 3D parametric models, describing both the petrophysical and geomechanical nature of the reservoir and surrounding rocks, including under-, side- and overburden rocks, were developed as the input for the simulation. A similar modeling workflow was used to develop the spatial distribution of a particular parameter. This included using the results of the interpretation of the well-log of the borehole profiles to determine the variation of the parameter in the vertical direction. The horizontal variability in the parameters exhibiting correlation with the compressional wave velocity was determined using the seismic cube as secondary data. Before statistical analyses, data were upscaled to the vertical resolution of the 3D grid (Figure 10A). During the geostatistical analyses, the relationship between input data was determined vertically and horizontally by adjusting the variogram parameters. This procedure was performed separately for distinguished lithostratigraphical intervals. An example of a variogram calculated in the vertical and horizontal direction to obtain the major and minor range of Young's modulus calculated for Middle Cambrian sandstones is shown in Figure 10B-D. During geostatistical analysis, we determined parameters characterizing the spatial variability of the modeled property for particular lithostratigraphic units. These parameters were then applied as steering criteria in the Gaussian random function simulation algorithm, calculating the distributions of the modeled property in 3D space (Figure 10E).

The remaining parameters that were not included in the available data set such as Biot constant, tensile strength, friction angle and dilation angle were assumed to be typical values for specific lithostratigraphic units (Tables 4 and 5), based on the literature [50-54].

Table 4. Assumed values of elastic and strength properties for the isotropic medium and surrounding rocks [50-54].

\begin{tabular}{cccc}
\hline Parameter (Unit) & Shales (Upper Boundary) & $\begin{array}{c}\text { Middle Cambrian } \\
\text { Sandstones (Reservoir) }\end{array}$ & Shales (Underburden) \\
\hline Young's modulus $(\mathrm{GPa})$ & Seismically derived 3D model & Seismically derived 3D model & 25 \\
Poisson's ratio & Seismically derived 3D model & Seismically derived 3D model & 0.35 \\
Rock density $\left(\mathrm{g} / \mathrm{cm}^{3}\right)$ & Seismically derived 3D model & Seismically derived 3D model & 2.42 \\
Biot constant & 1 & 1 & 1 \\
Porosity $(\%)$ & Seismically derived 3D model & Seismically derived 3D model & 8 \\
Unconfined compressive & Seismically derived 3D model & Seismically derived 3D model & 40 \\
strenght UCS $(\mathrm{MPa})$ & UCS $/ 14.035$ & UCS $/ 13.703$ & UCS/14.035 \\
Tensile strength $(\mathrm{MPa})$ & 30 & 35 & 30 \\
Friction angle $\left({ }^{\circ}\right)$ & 5 & 0 & 5 \\
Dilation angle $\left({ }^{\circ}\right)$ & & & \\
\hline
\end{tabular}

Table 5. Assumed values of elastic and strength properties for overburden rocks [50-54].

\begin{tabular}{|c|c|c|c|c|c|c|}
\hline Parameter (Unit) & $\begin{array}{l}\text { Cenozoic (Clays, } \\
\text { Sands, Gravel) }\end{array}$ & $\begin{array}{l}\text { Cretaceous } \\
\text { (Claystone) }\end{array}$ & $\begin{array}{c}\text { Jurassic } \\
\text { (Mudstone) }\end{array}$ & Anhydrite & Rock Salt & Dolomite \\
\hline $\begin{array}{l}\text { Young modulus } \\
\text { (GPa) }\end{array}$ & 0.1 & 1.5 & 5 & 55.5 & 1.4 & 83.81 \\
\hline Poisson's ratio & 0.3 & 0.31 & 0.15 & 0.26 & 0.44 & 0.2 \\
\hline $\begin{array}{l}\text { Rock density } \\
\left(\mathrm{g} / \mathrm{cm}^{3}\right)\end{array}$ & 1.9 & 2.6 & 2.27 & 2.85 & 2.17 & 2.82 \\
\hline Biot constant & 1 & 1 & 1 & 1 & 1 & 0.75 \\
\hline Porosity (\%) & 15 & 12 & 12 & 0 & 0 & 8 \\
\hline UCS (MPa) & 2.8 & 29 & 20 & 91.7 & - & 80 \\
\hline Tensile (MPa) & \multicolumn{6}{|c|}{ UCS/14.035 } \\
\hline Friction angle $\left({ }^{\circ}\right)$ & 30 & 30 & 22 & 29.4 & - & 45 \\
\hline Dilation angle $\left(^{\circ}\right)$ & 5 & 5 & 5 & 5 & - & 5 \\
\hline Cohesion (MPa) & - & - & - & - & 7.3 & - \\
\hline
\end{tabular}




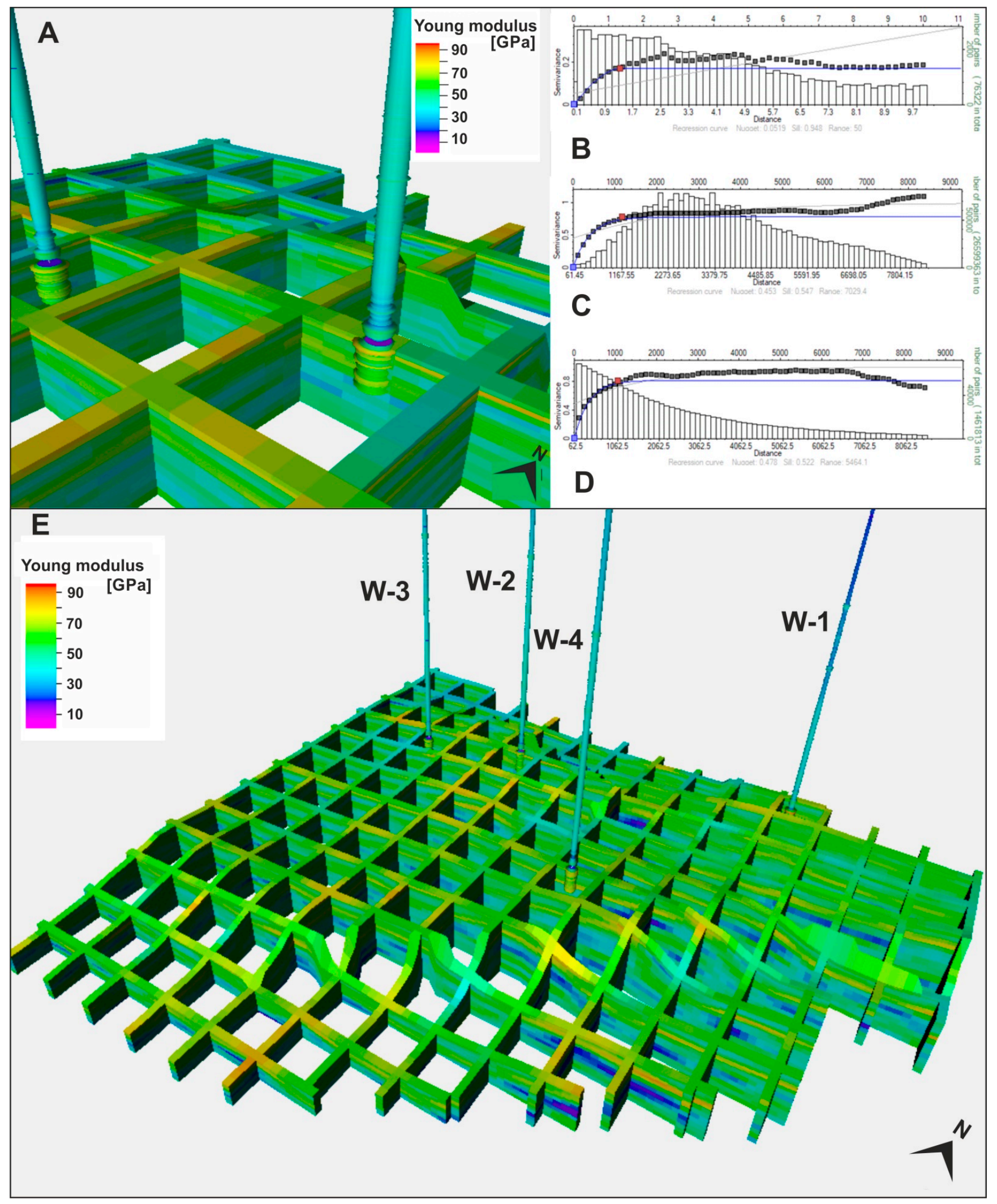

Figure 10. Diagram depicting different stages of the development of 3D parametric models: upscaling of well-log data (A), geostatistical analysis obtaining the vertical relationship (B), and horizontally in the direction of the highest (C) and lowest (D) correlation, and the calculated distribution of the parameters in 3D space (E). 
The calculated geomechanical simulation stress field provided the 3D distribution of the direction and magnitude of the principal stresses (Figure 11), which allowed us to optimize the trajectory of the horizontal sections of the boreholes for effective hydraulic fracturing treatment.

The direction of stresses is variable in the horizontal direction and is mostly affected by the system of discontinuities in the study area, around which the stresses tend to rotate. The maximum horizontal stress direction changes more visibly and rotates up to 30-40 toward the NNW direction in the areas located to the north from the W-2, W-3, and W-4 boreholes.

The application of the stimulation treatment can cause fault reactivation in neighboring faults and, consequently, the failure of the operation. However, the reverse tectonic regime probably maintained in the studied interval, confirmed via the hydraulic fracturing test and valid at least in overlying Ordovician strata, cause least stress perturbations on the fault planes and, therefore, least affect the stability of existing faults after treatment application [55,56]. Additionally, in reverse tectonic regime assumed also for Middle Cambrian sediments, the hydraulic fractures generated will tend to have orientation perpendicular to the fault plane [56]. Although the risk of the treatment failure still can occur due to the possible extension of the fracture to the fault plane, causing the leakage and loss of the fracturing fluid. Therefore, it is not recommended to plan the stimulation treatment of the Middle Cambrian sandstones near the faults.

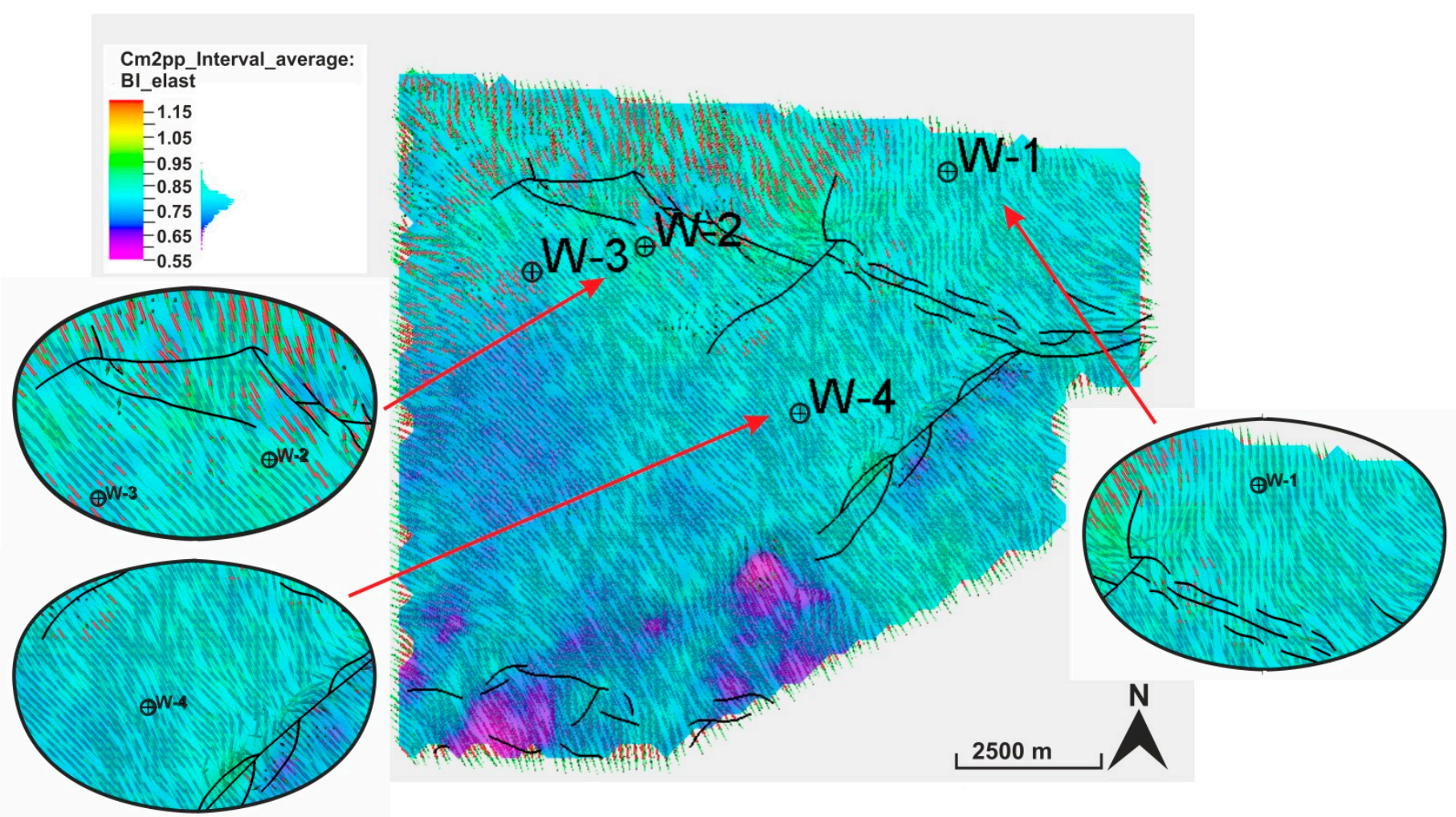

Figure 11. Distribution of the azimuth direction of the maximum horizontal stresses in the investigated sandstone interval (Cm2pp) with the BI distribution in the background. 
To achieve an effective stimulation treatment and apply hydraulic fracturing in an unconventional reservoir formation, the horizontal well should be drilled along the direction of the minimum horizontal stress so that the potential fractures can open perpendicular to the horizontal well section [38]. For the Cm2pp sandstone reservoir, the optimal direction of the horizontal boreholes is perpendicular to the direction of the maximum horizontal stress shown in Figure 11, which also indicates the direction of potentially generated hydraulic fractures. The variation in the horizontal stress direction needs to be considered when planning new horizontal boreholes.

Fractures occur when the value of the minimum principal stress at the borehole wall is below the tensile strength of the rock [57]. Using the calculated distributions of the principal horizontal stresses with the developed 3D distributions of tensile strength and pore pressure, it was possible to specify the fracturing pressure (Pfrac) by applying the following relationship in Equation (5) [57]:

$$
\text { Pfrac }=3 \times \sigma \mathrm{h}-\sigma \mathrm{H}+\mathrm{T}-\mathrm{Pp}
$$

where $\sigma \mathrm{h}$ and $\sigma \mathrm{H}$ are the magnitude of the minimum and maximum horizontal stress, respectively; T stands for the tensile strength; and $\mathrm{Pp}$ is the value of the pore pressure.

Comparing the average fracturing pressure values in the entire $\mathrm{Cm} 2$ interval to those in the reservoir zone of $\mathrm{Cm} 2 \mathrm{pp}$, we observed that the entire Middle Cambrian interval exhibits bimodal distribution in terms of the magnitude of fracturing pressure. In the northerly part of the study area, where boreholes W-1-4 are located, lower pressure (800 bar, on average) is enough to initiate hydraulic fractures (Figure 12A). However, to fracture the Middle Cambrian sediments in the southern part of the study area, higher pressures are required, with an average level of 1600 bar, reaching up to 2200 bar (Figure 12B). This bimodal distribution of the fracturing pressures occurs due to the higher contribution of weaker clay minerals abundant in the profile, especially in the uppermost and bottom-most part of the Middle Cambrian interval $\mathrm{Cm} 2$, possibly belonging to the Sarbsko and Osiek formations, respectively, developed as claystones, mudstones, and mudstone-sandstones.

Paradoxides Paradoxissimus sandstone formation requires much higher injection fluid pressures of 1200 to 2200 bars to fracture (Figure 12B). This is due to the very high strength of the quartzitic sandstones which for effective stimulation require high fracturing pressure levels. 


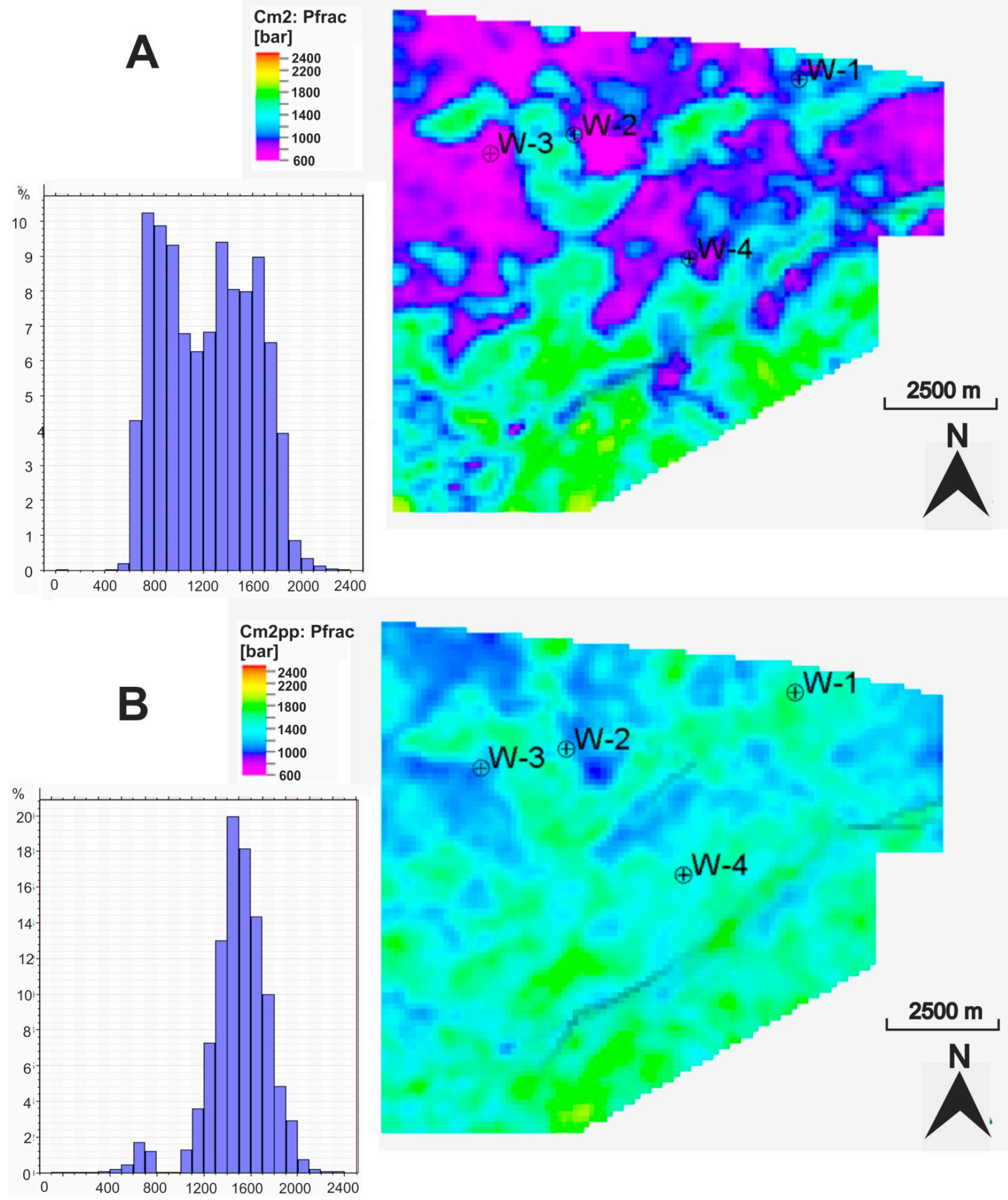

Figure 12. Average fracturing pressure in the Middle Cambrian formation $\mathrm{Cm} 2$ (A) and Paradoxides Paradoxissimus sandstones formation within in the Middle Cambrian CM2 interval (B). 


\section{Conclusions}

In this paper, we demonstrated the importance and wide range of applications of well-log data in the geomechanical evaluation of unconventional reservoir rocks.

The use of well-log data is an indispensable step in the geomechanical characterization of unconventional reservoir formations. Unconventional reservoir rock requires stimulation treatment to produce hydrocarbons at an economic level. Geomechanical properties and stress distribution were proved to play a critical role in optimizing the drilling location, trajectories of the horizontal sections of boreholes, and designing hydraulic fracturing treatments.

The petrophysical and geomechanical properties of the Middle Cambrian tight sandstones formation in Eastern Pomerania (north Poland) were evaluated simultaneously. This approach first determines the zones with prospective hydrocarbons saturation and help categorize the analyzed rock formation into the conventional or unconventional type. For the latter, stimulation treatment and geomechanical evaluation are also necessary.

In this study, based on laboratory, well-log, and seismic data, we developed 1D and 3D models of both petrophysical (density, porosity, permeability, mineralogical model, and formation fluids saturation) and geomechanical (elastic and strength) properties to determine the intervals that have the most potential in terms of hydrocarbons saturation and with favorable conditions for hydraulic fracturing.

The application of dipole sonic imaging, borehole microresistivity images, and conventional well logs help derive accurate and core-calibrated elastic and strength properties, the value of the vertical stress, and horizontal stress orientation. One of the essential elements during data preparation for geomechanical evaluation is the correct estimate of static elastic properties, which will be further used in geomechanical simulations via calibration of their dynamic equivalents calculated from the well-log data with the results of static laboratory measurements of these elastic properties.

The study of breakouts and drilling-induced fractures observed on high-resolution images of borehole walls allowed us to identify the horizontal stress direction, necessary for determining the boundary conditions used in geomechanical simulations.

The analysis of the petrophysical and geomechanical properties of the Middle Cambrian tight sandstones from Eastern Pomerania, north Poland, allowed us to draw detailed conclusions specific for this reservoir formation:

- The highest gas saturation with low shale volume was found in the top and middle parts of the reservoir.

- The petrophysical properties of Middle Cambrian sandstones, such as effective porosity and permeability, show variability. Based on the interpreted porosity ranging from $2-10 \%$, and permeability that mostly has values of a few millidarcy, not exceeding $100 \mathrm{mD}$, the analyzed reservoir is classified as tight sandstone requiring stimulation treatment for economic hydrocarbons production.

- In the analyzed sandstone profile, within gas saturated zones, the best properties in terms of effective reservoir stimulation treatment are characterized by Young's modulus valued ranging from 68-71 GPa, brittleness higher than BIe 0.69 and BI_it 0.8 , and Poisson's ratio values lower than 0.1

- The sediments of the Paradoxides Paradoxissimus interval of the Middle Cambrian age comprising quartzitic sandstones are, on average, more brittle compared to the entire Middle Cambrian sediments, with an average BI_e of 0.85. Cm2pp sandstones reveal a wide range of horizontal BI. The least-brittle sandstones are located in the northern part of the study area, while the sandstones with the highest brittleness are in the deeper buried area, located toward the south of the dislocation zones. The average brittleness of Middle Cambrian sediments is lowered by the contribution of less brittle component found especially in the top and bottom part in the profile of $\mathrm{Cm} 2$ sediments exhibiting an increased clay content.

- Determined relationships between static and dynamic elastic properties in the Middle Cambrian quarzitic sandstones are the following: E_stat $=1.23 \times$ E_dyn -19.86 and 
PR_stat $=0.7 \times$ PR_dyn +0.07 for Young modulus and Poisson's ratio, respectively. These relationships can be further used in the geomechanical analysis of sediments with similar lithology.

- The reverse tectonic regime in the study area affects the orientation of potentially generated hydraulic fractures, which tend to be oriented perpendicularly to the plane of existing faults. The variable direction of horizontal stresses calculated in geomechanical simulation should be considered when planning new horizontal boreholes.

- Comparing the average values of fracturing pressure in the entire $\mathrm{Cm} 2$ interval and those in Cm2pp reservoir zone, it can be observed that the Paradoxides Paradoxissimus quartzitic sandstone formation, due to very high strength, requires the application of higher fracturing pressure (1200-2200 bars).

The Middle Cambrian tight sandstone formation in the research area is an interesting formation to study mainly due to its hydrocarbon potential. However, until the present, it has not been very well recognized. There are still many unanswered questions, e.g., resulting from missing sedimentological and petrographical studies. Involving those in future research, by analyzing the core material and combining it with the results of well log and seismic data interpretation, would help us better recognize the formation, especially in defining boundaries between particular lithostratigraphic units. All these would improve understanding of the spatial distribution of these units to identify the best candidate for stimulation treatment.

Author Contributions: Conceptualization, M.S.-V., A.L.-Ś.; methodology, M.S.-V. and A.L.-Ś.; software, M.S.-V. and A.L.-Ś.; validation, M.S.-V. and A.L.-Ś.; formal analysis, M.S.-V. and A.L.-Ś.; investigation, M.S.-V. and A.L.-Ś.; resources, M.S.-V. and A.L.-Ś.; data curation, M.S.-V. and A.L.-Ś.; writing — original draft preparation, M.S.-V. and A.L.Ś.; writing—review and editing, M.S.-V.; visualization, M.S.-V. and A.L.-Ś.; supervision, M.S.-V.; project administration, M.S.-V. All authors have read and agreed to the published version of the manuscript.

Funding: This research was funded by the Polish Ministry of Science and Higher Education, Grant No. DK-4100-61/21. The authors would like to express their gratitude to the Polish Ministry of Science and Higher Education for funding this research.

Data Availability Statement: The data supporting the findings of this research are available on reasonable request from the corresponding author.

Conflicts of Interest: The authors declare no conflict of interest.

\section{References}

1. Huang, J.; Ma, X.; Safari, R.; Mutlu, U.; McClure, M. Hydraulic Fracture Design Optimization for Infill Wells: An Integrated Geomechanics Workflow. In Proceedings of the 49th US Rock Mechanics/Geomechanics Symposium, San Francisco, CA, USA, 28 June-1 July 2015.

2. Taghichian, A.; Hashemalhoseini, H.; Zaman, M.; Yang, Z.-Y. Geomechanical Optimization of Hydraulic Fracturing in Unconventional Reservoirs: A Semi-Analytical Approach. Int. J. Fract. 2018, 213, 107-138. [CrossRef]

3. Iferobia, C.C.; Ahmad, M. A Review on the Experimental Techniques and Applications in the Geomechanical Evaluation of Shale Gas Reservoirs. J. Nat. Gas Sci. Eng. 2020, 74, 103090. [CrossRef]

4. Podhalańska, T.; Waksmundzka, M.I.; Becker, A.; Roszkowska-Remin, J.; Dyrka, I.; Feldman-Olszewska, A.; Głuszyński, A.; Grotek, I.; Janas, M.; Karcz, P.; et al. Prospective Zones for Unconventional Hydrocarbon Resources in Cambrian, Ordovician, Silurian and Carboniferous Rocks of Poland: Integration of the Research Results. Przeglad Geologiczny 2016, 64, $1008-1021$.

5. Such, P.; Leśniak, G.; Mroczkowska-Szerszeń, M.; Dudek, L.; Cicha-Szot, R.; Spunda, K. Methodology of Pore Space Analysis in Shale Rocks. Pract. Nauk. Inst. Naft. Gazu 2017, 214, 1-154.

6. Leśniak, G.; Sowiżdżał, K.; Stadtmúller, M.; Lis-Śledziona AKaczmarczyk, W.; Słota-Valim, M.; Kasza, P. Wykonanie Niestandardowych Kompleksowych Bada N Petrofizycznych I Geomechanicznych Na Próbkach I Danych Z Dolnopaleozoicznych Łupków; Technical Report, Shalemech No. 3; INiG-PIB: Kraków, Poland, 2017.

7. Jarzyna, J.; Bała, M.; Krakowska, P.; Puskarczyk, E.; Strzępowicz, A.; Wawrzyniak-Guz, K.; Więcław, D.; Ziętek, J. Shale Gas in Poland. In Advances in Natural Gas. Emerging Technologies; al Megren, H.A., Altamini, R.H., Eds.; BoD-Books on Demand: Norderstedt, Germany, 2017. 
8. Sowiżdżał, K.; Słoczyński, T.; Stadtmúller, M.; Kaczmarczyk, W. Lower Palaeozoic Petroleum Systems of the Baltic Basin in Northern Poland: A 3D Basin Modeling Study of Selected Areas (onshore and offshore). Interpretation 2018, 6, SH117-SH132. [CrossRef]

9. Stadtmuller, M.; Lis-Śledziona, A.; Słota-Valim, M. Petrophysical and Geomechanical Analysis of the Lower Paleozoic Shale Formation, North Poland. Interpretation 2018, 6, SH91-SH106. [CrossRef]

10. Wilczynski, P.; Domonik, A.; Lukaszewski, P. Anisotropy of Strength and Elastic Properties of Lower Paleozoic Shales from the Baltic Basin, Poland. Energies 2021, 14, 2995. [CrossRef]

11. Więcław, D.; Kotarba, M.J.; Kosakowski, P.; Kowalski, A. Habitat and Hydrocarbon Potential of the Lower Palaeozoic Source Rocks of the Polish Sector of the Baltic Basin. Geol. Q. 2010, 54, 159-182.

12. Modliński, Z.; Podhalańska, T. Outline of the Lithology and Depositional Features of the Lower Paleozoic Strata in the Polish Part of the Baltic Region. Geol. Q. 2010, 54, 109-121.

13. Bała, M. Charakterystyka parametrów sprężystych określonych Na Podstawie pomiarów Geofizyki Otworowej I Modelowań Teoretycznych W Wybranych Formacjach W Otworach Basenu bałtyckiego I Wierconych Na Szelfie. Nafta Gaz 2017, 73, 558-570. [CrossRef]

14. Dadlez, R. Phanerozoic Basinal Evolution Along the Teisseyre-Tornquist Zone. Kwartalnik Geologiczny 1987, 31, 263-278, (In Polish with English Summary).

15. Dadlez, R. Tectonics of the Southern Baltic. Kwartalnik Geologiczny 1990, 34, 1-20, (In Polish with English Summary).

16. Jaworowski, K. Transgresja Morza Kambryjskiego W północnej Polsce. Pr. Inst. Geol. 1979, 94, 5-80.

17. Jaworowski, K. Warunki Sedymentacji osadów Prekambru I Kambru W północnej Polsce. Przegląd Geologiczny 1982, 30, $220-224$.

18. Jaworowski, K. Facies Variability in the Cambrian Deposits from the Koscierzyna and Gdansk Sections (Pomeranian Caledonides Foreland, Northern Poland): A Comparative Study. Geol. Q. 2000, 44, 249-260.

19. Kotarba, M.J.; Nagao, K. Molecular and Isotopic Compositions and Origin of Natural Gases from Cambrian and CarboniferousLower Permian Reservoirs of the Onshore Polish Baltic Region. Acta Diabetol. 2014, 104, 241-261. [CrossRef]

20. Kosakowski, P.; Wróbel, M.; Poprawa, P. Hydrocarbon Generation and Expulsion Modelling for the Lower Palaeozoic Source Rocks in the Polish Part of the Baltic Region. Geol. Q. 2010, 54, 241-256.

21. Kosakowski, P.; Kotarba, M.J.; Piestrzyński, A.; Shogenova, A.; Więcław, D. Petroleum Source Rock Evaluation of the Alum and Dictyonema Shales (Upper Cambrian-Lower Ordovician) in the Baltic Basin and Podlasie Depression (eastern Poland). Int. J. Earth Sci. 2016, 106, 743-761. [CrossRef]

22. Poprawa, P.; Šliaupa, S.; Stephenson, R.; Lazauskien, J. Late Vendian-Early Palæozoic Tectonic Evolution of the Baltic Basin: Regional Tectonic Implications from Subsidence Analysis. Tectonophysics 1999, 314, 219-239. [CrossRef]

23. Processing and interpretation of 3D seismic data from the study area. 2013; unpublished report.

24. Schleicher, M.; Köster, J.; Kulke, H.; Weil, W. Reservoir and Source Rock Characterisation of the Early Palaeozoic in-Terval in the Peribaltic Syneclise, Northern Poland. J. Petrol. Geol. 1998, 21, 33-56. [CrossRef]

25. Golonka, J.; Porębski, S.J.; Barmuta, J.; Papiernik, B.; Bębenek, S.; Barmuta, M.; Botor, D.; Pietsch, K.; Słomka, T. Palaeozoic Palaeogeography of the East European Craton (Poland) in the Framework of Global Plate Tectonics. Ann. Soc. Geol. Pol. 2019, 87, 10. [CrossRef]

26. Leśniak, G.; Stadtmüller, M. Interpretation of the results of core material, cuttings and reservoir fluids (natural gas, crude oil) from W1, W-2, W-3 and W-4 boreholes in terms of hydrocarbons exploration in the Ordovician-Silurian shale formations. Unpublished report. 2012; Kraków.

27. Herwanger, J.; Koutsabeloulis, N. Rock Physics for Geomechanics. In Seismic Geomechanics: How to Build and Calibrate Geomechanical Models Using 3D and 4D Seismic Data; EAGE Publications: Houten, The Netherlands, 2011; pp. 181-182.

28. Jarvie, D.M.; Hil, R.J.; Ruble, T.E.; Pollastro, R.M. Unconventional Shale Gas System: The Mississippian Barnet Shale of NorthCentral Texas as One Model for Thermogenic Shale Gas Assessment. AAPG Bull. 2007, 91, 475-499. [CrossRef]

29. Tingay, M.; Reinecker, J.; Birgit, M. Borehole Breakout and Drilling-Induced Fracture Analysis from Image Logs; World Stress Map Project- guidelines: Image Logs, Helmholtz Vent. Potsdam, GFZ.2008:pp. 1-18.

30. Li, H.; Tang, H.; Qin, Q.; Zhou, J.; Qin, Z.; Fan, C.; Su, P.; Wang, Q.; Zhong, C. Characteristics, Formation Periods and Genetic Mechanisms of Tectonic Fractures in the Tight Gas Sandstones Reservoir: A Case Study of Xujiahe Formation in YB Area, Sichuan Basin. China J. Petrol. Sci. Eng. 2019, 178, 723-735. [CrossRef]

31. Dubinya, N.V. An Overview of Wellbore Methods of Investigating Stress State of the Upper Layers of the Earth's Crust. Izvestiya Phys. Solid Earth 2019, 55, 311-326. [CrossRef]

32. Sone, H.; Zoback, M.D. Viscous Relaxation Model for Predicting Least Principal Stress Magnitudes Insedimentary Rock. J. Petrol. Sci. Eng. 2014, 124, 416-431. [CrossRef]

33. Zoback, M.D.; Moos, D.; Mastin, L.G.; Anderson, R.N. Well Bore Breakouts and in Situ Stress. J. Geophys. Res. 1985, 90, 5523-5530. [CrossRef]

34. Bell, J.S. Investigating Stress Regimes in Sedimentary Basins Using Information from Oil Industry Wireline Logs and Drilling Records. In Geological Applications of Wireline Logs; Hurst, A., Lovell, M., Morton, A., Eds.; Geological Society Special Publications: London, UK, 1990; Volume 48, pp. 305-325.

35. Moos, D. In Situ Stress Measurements in the NPR Hole, Volume I - Results and Interpretations. In Off. Sci. Tech. Inf. Tech. Rep; 2001. Available online: https:/ / www.osti.gov/servlets/purl/787831 (accessed on 5 August 2021). [CrossRef] 
36. Zoback, M.D.; Healy, J.H. In Situ Stress Measurements to $3.5 \mathrm{Km}$ Depth in the Cajon Pass Scientific Research Drill Hole: Implications for the Mechanics of Crustal Faulting. J. Geophys. 1992, 97, 5039-5057. [CrossRef]

37. Bell, J.S.; Gough, D.I. Northeast-Southwest Compressive Stress in Alberta: Evidence from Oil Wells. Earth Planet. Sci. Lett. 1979, 45, 475-482. [CrossRef]

38. Zillur, R.; Adnan, A.A.-K.; Hamoud, A.A.-A.; Mahbub, S.A. Succesfull Drilling of Lateral Wells in Minimum Horizontal Stress Direction for Optimal Fracture Placement. Oil Gas. J. 2012, 110, 74-83.

39. Wikel, K. Geomechanics: Bridging the Gap from Geophysics to Engineering in Unconventional Reservoirs. First Break 2011, 29, 71-80. [CrossRef]

40. Terzaghi, K. Stress Conditions for the Failure of Saturated Concrete and Rock. In From Theory to Practice in Soil Mechanics; John Wiley and Sons: Hoboken, NJ, USA, 1945; pp. 181-197.

41. Swabrick, R.E. Challenges of Porosity-Based Pore Pressure Prediction. CSEG Rec. 2002, 27, 75-77.

42. Boer, L.; Sayers, C.; Nagy, Z.; Hooyman, P.J. Pore Pressure Prediction Using Well-Conditioned Seismic Velocities. First Break 2006, $24,43-49$.

43. Bowers, G. Pore Pressure Estimation from Velocity Data: Accounting for Overpressure Mechanisms Besides Undercompaction. SPE Drill. Complet. 1995, 10, 89-95. [CrossRef]

44. Sayers, C.M.; Johnson, G.M.; Denyer, G. Predrill Pore-Pressure Prediction Using Seismic Data. Geophysics 2002, 67, 1286-1292. [CrossRef]

45. Bourgoyne, A.T.; Millheim, K.K.; Chenevert, M.E.; Young, F.S. Applied Drilling Engineering. Textbook Series; Society of Petroleum Engineers: Richardson, TX, USA, 1986; Volume 2.

46. Bowman, T. Direct Method for Determining Organic Shale Potential from Porosity and Resistivity Logs to Identify Possible Resource Plays. In Proceedings of the AAPG Annual Convention \& Exhibition, New Orleans, LA, USA, 11-14 April 2010.

47. Li, M. Chapter 7-Prestack Seismic Inversion and Seismic Attribute Analysis. In Geophysical Exploration Technology; Li, M., Zhao, Y., Eds.; Elsevier: Amsterdam, The Netherlands, 2014; pp. 199-219. ISBN 9780124104365. [CrossRef]

48. Zou, C. Calculation of Brittleness Index for Rock Elastic Parameters. In Unconventional Petroleum Geology, 2nd ed.; Zou, C., Ed.; Elsevier: Amsterdam, The Netherlands, 2017; ISBN 9780128122341. [CrossRef]

49. Shogenov, K.; Shogenovaa, A.; Vizika-Kavvadiasb, O.; Nauroy, J.-F. Reservoir quality and petrophysical properties of Cambrian sandstones and their changes during the experimental modelling of CO2 storage in the Baltic Basin. Estonian J. Earth Sci. 2015, 64, 199-217. [CrossRef]

50. Handin, J.; Hager, R.V. Experimental Deformation of Sedimentary Rocks under Confining Pressure: Tests at Room Temperature on Dry Samples. Bull. Am. Assoc. Pet. Geol. 1957, 41,1-51.

51. Wines, D.; Lilly, P. Estimates of Rock Joint Shear Strength in Part of the Fimiston Open Pit Operation in Western Australia. Int. J. Rock Mech. Min. Sci. 2003, 40, 929-937. [CrossRef]

52. Smith, S.A.F.; Faulkner, D.R. Laboratory Measurements of the Frictional Properties of the Zuccale Low-Angle Normal Fault, Elba Island, Italy. J. Geophys. Res. Space Phys. 2010, 115, 115. [CrossRef]

53. Kwaśniewski, M.; Rodriguez-Oitaben, P. Study on the Dilatancy Angle of Rocks in the Pre-Failure Domain. In Harmonizing Rock Engineering and the Environment; Qian, Q., Zhou, Y., Eds.; Taylor and Francis Group: London, UK, 2012; pp. $681-686$.

54. Pinazzi Da Silva Ribeiro, P.C.; Mello Oliveira, M.; Nelson, P. Correlation Between Uniaxial Compressive Strength and Brazilian Tensile Strength Using Different Rock Types. In Proceedings of the ISRM VII Brazilian Symposium on Rock Mechanics, Belo Horizonte, MG, Brazil, 19-26 October 2016. Paper Number: ISRM-SBMR-2016-01.

55. Cheng, Y. Boundary Element Analysis of the Stress Distribution Around Multiple Fractures: Implications for the Spacing of Perforation Clusters of Hydraulically Fractured Horizontal Wells. In Proceedings of the SPE Eastern Regional Meeting, Charleston, WV, USA, 23-25 September 2009. [CrossRef]

56. Gao, Q.; Cheng, Y.; Fathi, E.; Ameri, S. Analysis of Stress-Field Variations Expected on Subsurface Faults and Discontinuities in the Vicinity of Hydraulic Fracturing. Spe Reserv. Eval. Eng. 2016, 19, 54-69.

57. Lavrov, A. Mechanisms and Diagnostics of Lost Circulation. In Lost Circulation; Elsevier BV: Amsterdam, The Netherlands, 2016; pp. 99-162. [CrossRef] 